\title{
Serotonin-enhanced hyperactivation of hamster sperm
}

\author{
Masakatsu Fujinoki \\ Department of Physiology, School of Medicine, Dokkyo Medical University, Mibu, Tochigi 321-0293, Japan \\ Correspondence should be addressed to M Fujinoki; Email: fujinoki@dokkyomed.ac.jp
}

\begin{abstract}
The effects of serotonin on reproductive function were examined using hamster spermatozoa. When serotonin at concentrations from $1 \mathrm{fmol} / \mathrm{l}$ to $1 \mu \mathrm{mol} / \mathrm{I}$ was added to modified Tyrode's albumin lactate pyruvate (mTALP) medium, hyperactivation was significantly enhanced. Agonists and antagonists of 5-hydroxytryptamine hydrochloride $(5-\mathrm{HT})$ receptors $\left(5-\mathrm{HT}_{2}\right.$ and 5 - $\mathrm{HT}_{4}$ receptors) were added to the medium. Both $5-\mathrm{HT}_{2}$ and $5-\mathrm{HT}_{4}$ receptor agonists significantly enhanced hyperactivation, although the effect was greater than the former. However, both $5-\mathrm{HT}_{2}$ and $5-\mathrm{HT}_{4}$ receptor antagonists significantly suppressed serotonin-enhanced hyperactivation, with the former suppressing stimulation by a lower concentration of serotonin than the latter. These results indicate that serotonin enhances hyperactivation via $5-\mathrm{HT}_{2}$ and/or $5-\mathrm{HT}_{4}$ receptors in a dose-dependent manner.
\end{abstract}

Reproduction (2011) $\mathbf{1 4 2} 255-266$

\section{Introduction}

The neurotransmitter serotonin (5-hydroxytryptamine hydrochloride or $5-\mathrm{HT}$ ) is formed in the body by the hydroxylation and decarboxylation of tryptophan. After release from serotonergic neurons, serotonin is recaptured by an active reuptake mechanism and inactivated by monoamine oxidase to form 5 -hydroxyindoleacetic acid, the principal urinary metabolite of serotonin. In the pineal gland, serotonin is converted to $\mathrm{N}$-acetyl5-methoxytryptamine (melatonin). Serotonin has multiple actions in diverse tissues. In general, serotonin actions are mediated by 5-HT receptors, characterized, and cloned as $5-\mathrm{HT}_{1}, 5-\mathrm{HT}_{2}, 5-\mathrm{HT}_{3}, 5-\mathrm{HT}_{4}, 5-\mathrm{HT}_{5}$, $5-\mathrm{HT}_{6}$, and $5-\mathrm{HT}_{7}$ receptors. Most $5-\mathrm{HT}$ receptors are G-protein-coupled receptors and act on adenylyl cyclase (AC) or phospholipase $\mathrm{C}$ (PLC). 5- $\mathrm{HT}_{3}$ receptors, however, are ion channel-coupled receptors (Noda et al. 2004, Ganong 2005).

Because serotonin and 5-HT receptors are found in oocytes, cumulus-oocyte complexes (COC), follicular fluid, and embryos in mammals (Dubé \& Amireault 2007), some consider that serotonergic signals are associated with regulation of steroidogenesis, oocyte maturation, and embryonic development. Another study (Meizel \& Turner 1983) demonstrated that serotonin and 5-methoxytryptamine, a 5- $\mathrm{HT}_{4}$ receptor agonist, induce an acrosome reaction (AR) in hamster spermatozoa. They also demonstrated that serotonin-induced and serotonin agonist-induced ARs were inhibited by $4-(5 \mathrm{H}$ dibenzo[a, d] cyclohepten-5-ylidene)-1-methyl-,hydrochloride,hydrate (2:3) (cyproheptadine hydrochloride sesquihydrate or piperidine), a $5-\mathrm{HT}_{2}$ receptor antagonist (Meizel \& Turner 1983).

Mammalian spermatozoa are capacitated before fertilization. Capacitated spermatozoa exhibit the AR in their heads and hyperactivation of the flagella (Yanagimachi 1994, Fujinoki 2009). The AR is a modified exocytotic event involving an acrosome and is required for penetration of the zona pellucida (ZP) of the egg and sperm-egg plasma membrane fusion (Yudine et al. 1988, Yanagimachi 1994). Hyperactivation is a specialized movement of the sperm flagellum that creates the propulsive force for penetration of the ZP. Hyperactivated spermatozoa exhibit a high amplitude, asymmetrical beating pattern of the sperm flagellum (Yanagimachi 1994, Fujinoki et al. 2001 a, Suarez \& Ho 2003). Capacitation occurs artificially in a specific culture medium containing albumin, $\mathrm{HCO}_{3}^{-}$, and $\mathrm{Ca}^{2+}$. Albumin is an essential component for capacitation to occur (Fujinoki 2008, Noguchi et al. 2008), as it removes cholesterol from the sperm plasma smembrane to change its fluidity (Langlais \& Roberts 1985). $\mathrm{HCO}_{3}^{-}$ stimulates AC, thereby increasing cAMP levels (Okamura et al. 1985). cAMP activates protein kinase A (PKA), leading to protein serine/threonine phosphorylation and to sperm flagellar movement (Visconti \& Kopf 1998, Visconti et al. 1999, Fujinoki et al. 2003, 2004a, 2004b, 2006). In many cases, protein tyrosine phosphorylation also occurs in a cAMP-dependent manner (Visconti et al. 1995, 1999, Visconti \& Kopf 1998, Fujinoki et al. 2001b). $\mathrm{Ca}^{2+}$ is involved in many intracellular signal transductions, including regulation of AC, and phosphodiesterase and protein 
phosphorylation (Visconti \& Kopf 1998, Visconti et al. 1998, Ho \& Suarez 2001, Breitbart 2002, Ho et al. 2002, Marín-Briggiler et al. 2005).

Several studies have demonstrated that the $A R$ is induced by ligands such as progesterone, the ZP, serotonin, and melatonin (Meizel \& Turner 1983, Osman et al. 1989, Luconi et al. 2004, Baldi et al. 2009, Casao et al. 2009). However, hyperactivation is also enhanced by ligands such as progesterone and melatonin (Sueldo et al. 1993, Yang et al. 1994, Fujinoki 2008, 2009, Noguchi et al. 2008, du Plessis et al. 2010). Moreover, progesterone-enhanced hyperactivation was suppressed by $17 \beta$-estradiol (Fujinoki 2010). These ligands regulate the $A R$ and hyperactivation via nongenomic regulation. Non-genomic regulation of the $A R$ and hyperactivation by progesterone and the ZP are associated with $\mathrm{Ca}^{2+}$ signals via PLC (Luconi et al. 2004, Noguchi et al. 2008, Baldi et al. 2009, Fujinoki 2009). However, non-genomic regulation of the AR and hyperactivation by melatonin are associated with nitric oxide signals (Fujinoki 2008, 2009, Casao et al. 2009, du Plessis et al. 2010). However, regulation of the AR by serotonin is poorly understood. Moreover, it has yet to be determined whether serotonin enhances hyperactivation, although it is known to induce the AR (Meizel \& Turner 1983). Accordingly, in this study, the effects of serotonin on hyperactivation using hamster spermatozoa were investigated.

\section{Results}

\section{Effects of serotonin on hyperactivation}

In a previous study (Fujinoki 2008), hyperactivation was significantly enhanced when melatonin at concentrations between $1 \mathrm{fmol} / \mathrm{l}$ and $10 \mu \mathrm{mol} / \mathrm{l}$ was added to the Tyrode's albumin lactate pyruvate (mTALP) medium. As melatonin is a metabolite of serotonin, it was examined whether serotonin enhanced hyperactivation. Serotonin at concentrations between $1 \mathrm{fmol} / \mathrm{l}$ and $1 \mu \mathrm{mol} / \mathrm{I}$ significantly enhanced hyperactivation (Fig. 1A), but serotonin did not affect the percentage of motile spermatozoa when added to the TALP medium at concentrations between $1 \mathrm{amol} / \mathrm{l}$ and $10 \mu \mathrm{mol} / \mathrm{l}$ (data not shown). With incubation for $0 \mathrm{~h}$, no hyperactivated spermatozoa were seen (Fig. 1A). After incubation for $0.5 \mathrm{~h}$, there were a few hyperactivated spermatozoa, but serotonin did not enhance hyperactivation (Fig. 1A). After incubation for $1 \mathrm{~h}$ (Fig. 1B), $100 \mathrm{nmol} / \mathrm{l}$ serotonin significantly enhanced hyperactivation in comparison with mTALP or $1 \mathrm{amol} / \mathrm{l}$ serotonin. Hyperactivation was significantly enhanced by $10 \mathrm{nmol} / \mathrm{l}$ serotonin in comparison with mTALP or serotonin at 1 or $10 \mathrm{amol} / \mathrm{l}$. Similarly, hyperactivation was significantly enhanced by $10 \mathrm{pmol} / \mathrm{l}$ serotonin in comparison with $\mathrm{mTALP}$ or serotonin at $1 \mathrm{amol} / \mathrm{l}, 10 \mathrm{amol} / \mathrm{l}, 1 \mu \mathrm{mol} / \mathrm{l}$, or $10 \mu \mathrm{mol} / \mathrm{l}$. Hyperactivation was significantly enhanced by serotonin at concentrations between $1 \mathrm{fmol} / \mathrm{l}$ and $1 \mathrm{pmol} / \mathrm{l}$, as well as $100 \mathrm{pmol} / \mathrm{l}$ and $1 \mathrm{nmol} / /$ serotonin, in comparison with mTALP or serotonin at $1 \mathrm{amol} / \mathrm{l}, 10 \mathrm{amol} / \mathrm{l}$, or $10 \mu \mathrm{mol} / \mathrm{l}$. Although the increase was not significant,
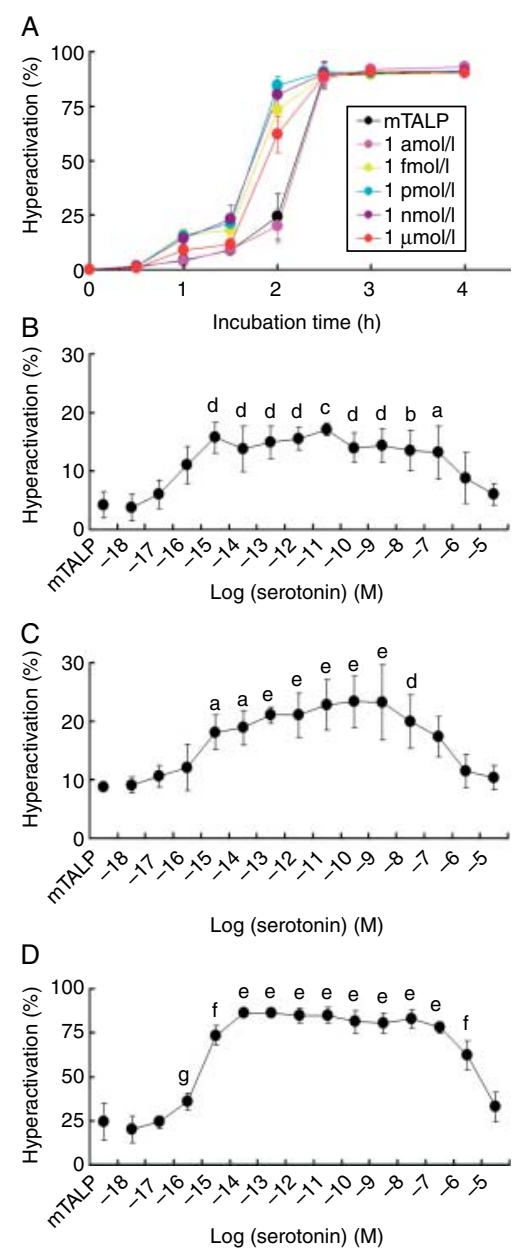

Figure 1 Dose-dependent effects of serotonin on hyperactivation. The percentage of hyperactivated spermatozoa is shown (A) as an overview of effects after incubation for (B) 1, (C) 1.5, and (D) $2 \mathrm{~h}$ after serotonin was added to mTALP medium. Data are given as mean \pm s.D. (mTALP): $\mathrm{mTALP}$; $(1 \mathrm{amol} / \mathrm{l}$ or -18$)$ : $\mathrm{mTALP}+1 \mathrm{amol} / \mathrm{l}$ serotonin; $(-17)$ : $\mathrm{mTALP}+10 \mathrm{amol} / \mathrm{l}$ serotonin; $(-16): \mathrm{mTALP}+100 \mathrm{amol} / \mathrm{l}$ serotonin; $(1 \mathrm{fmol} / \mathrm{l}$ or -15$)$ : $\mathrm{mTALP}+1 \mathrm{fmol} / \mathrm{l}$ serotonin; $(-14)$ : mTALP + $10 \mathrm{fmol} / /$ serotonin; $(-13): \mathrm{mTALP}+100 \mathrm{fmol} / \mathrm{l}$ serotonin; $(1 \mathrm{pmol} / \mathrm{l}$ or -12$): \mathrm{mTALP}+1 \mathrm{pmol} / \mathrm{l}$ serotonin; $(-11): \mathrm{mTALP}+10 \mathrm{pmol} / \mathrm{l}$ serotonin; $(-10)$ : $\mathrm{mTALP}+100 \mathrm{pmol} / \mathrm{l}$ serotonin; $(1 \mathrm{nmol} / \mathrm{l}$ or -9$)$ : $\mathrm{mTALP}+1 \mathrm{nmol} / \mathrm{l}$ serotonin; $(-8): \mathrm{mTALP}+10 \mathrm{nmol} / \mathrm{l}$ serotonin; $(-7): \mathrm{mTALP}+100 \mathrm{nmol} / \mathrm{l}$ serotonin; $(1 \mu \mathrm{mol} / \mathrm{l}$ or -6$): \mathrm{mTALP}$ $+1 \mu \mathrm{mol} / \mathrm{l}$ serotonin; $(-5): \mathrm{mTALP}+10 \mu \mathrm{mol} / \mathrm{l}$ serotonin. ${ }^{\mathrm{a}}$ Significant difference in comparison with mTALP or $1 \mathrm{amol} / /$ serotonin; ${ }^{\mathrm{b}}$ significant difference in comparison with mTALP or $1 \mathrm{amol} / \mathrm{l}$ or $10 \mathrm{amol} / \mathrm{l}$ serotonin; ${ }^{\mathrm{c}}$ significant difference in comparison with mTALP or $1 \mathrm{amol} / \mathrm{l}, 10 \mathrm{amol} / \mathrm{l}, 1 \mu \mathrm{mol} / \mathrm{l}$, or $10 \mu \mathrm{mol} / / \mathrm{l}$ serotonin; ${ }^{\mathrm{d}}$ significant difference in comparison with mTALP or $1 \mathrm{amol} / \mathrm{l}, 10 \mathrm{amol} / \mathrm{l}$, or $10 \mu \mathrm{mol} / / \mathrm{l}$ serotonin; ${ }^{\mathrm{e}}$ significant difference in comparison with mTALP or between $1 \mathrm{amol} / \mathrm{l}$ and $100 \mathrm{amol} / \mathrm{l}, 1 \mu \mathrm{mol} / \mathrm{l}$, and $10 \mu \mathrm{mol} / \mathrm{l}$ serotonin; ${ }^{f}$ significant difference in comparison with mTALP or between $1 \mathrm{amol} / \mathrm{l}$ and $100 \mathrm{amol} / \mathrm{l}$ or $10 \mu \mathrm{mol} / \mathrm{l}$ serotonin; ${ }^{\mathrm{g}}$ significant difference in comparison with $1 \mathrm{amol} / \mathrm{l}$ or between $1 \mathrm{fmol} / \mathrm{l}$ and $1 \mu \mathrm{mol} / \mathrm{l}$ serotonin. 
serotonin at $100 \mathrm{amol} / \mathrm{l}$ enhanced hyperactivation. After incubation for $1.5 \mathrm{~h}$ (Fig. 1C), serotonin at 1 and $10 \mathrm{fmol} / \mathrm{I}$ significantly enhanced hyperactivation in comparison with mTALP or serotonin at $1 \mathrm{amol} / \mathrm{l}$. Hyperactivation was significantly enhanced by $10 \mathrm{nmol} / \mathrm{l}$ serotonin in comparison with $\mathrm{mTALP}$ or serotonin at $1 \mathrm{amol} / \mathrm{l}, 10 \mathrm{amol} / \mathrm{l}$, or $10 \mu \mathrm{mol} / \mathrm{l}$. Moreover, serotonin at concentrations between $100 \mathrm{fmol} / \mathrm{l}$ and $1 \mathrm{nmol} / \mathrm{l}$ significantly enhanced hyperactivation in comparison with mTALP or serotonin at concentrations between $1 \mathrm{amol} / \mathrm{l}$ and $100 \mathrm{amol} / \mathrm{l}, 1 \mu \mathrm{mol} / \mathrm{l}$, or $10 \mu \mathrm{mol} / \mathrm{l}$. After incubation for $2 \mathrm{~h}$ (Fig. 1D), serotonin at concentrations between $10 \mathrm{pmol} / \mathrm{l}$ and $100 \mathrm{nmol} / \mathrm{l}$ significantly enhanced hyperactivation in comparison with mTALP or serotonin at concentrations between $1 \mathrm{amol} / \mathrm{l}$ and $100 \mathrm{amol} / \mathrm{l}, 1 \mu \mathrm{mol} / \mathrm{l}$, or $10 \mu \mathrm{mol} / \mathrm{l}$. Serotonin at $1 \mathrm{fmol} / \mathrm{l}$ and $1 \mu \mathrm{mol} / /$ significantly enhanced hyperactivation in comparison with mTALP or serotonin at concentrations between $1 \mathrm{amol} / \mathrm{l}$ and $100 \mathrm{amol} / \mathrm{l}$ and $10 \mu \mathrm{mol} / /$ serotonin. Moreover, serotonin at $100 \mathrm{amol} / \mathrm{l}$ significantly enhanced hyperactivation compared with serotonin at $1 \mathrm{amol} / \mathrm{l}$ or concentrations between $1 \mathrm{fmol} / \mathrm{l}$ and $1 \mu \mathrm{mol} / \mathrm{l}$. After incubation for $2.5,3$, and $4 \mathrm{~h}$, most motile spermatozoa were hyperactivated under all conditions (Fig. 1A).

\section{Effects of 5-HT receptor agonists on hyperactivation}

Quipazine is a nonspecific 5-HT receptor agonist, although Meizel \& Turner (1983) reported that it was a 5-HT receptor antagonist and significantly suppressed serotonin-induced AR. Accordingly, it was examined whether quipazine acted as an antagonist to serotoninenhanced hyperactivation using $100 \mathrm{pmol} / \mathrm{l}$ serotonin, an average value of the effective concentrations, and $1 \mu \mathrm{mol} / \mathrm{l}$ quipazine (Fig. 2). Although $1 \mu \mathrm{mol} / \mathrm{l}$ quipazine did not affect the percentage of motile spermatozoa (data not shown), it significantly enhanced hyperactivation (Fig. 2A). After incubation for 0 and $0.5 \mathrm{~h}$, no hyperactivated spermatozoa were seen (Fig. 2A). After incubation for 1 (Fig. 2B), 1.5 (Fig. 2C), and 2 h (Fig. 2D), serotonin and quipazine significantly enhanced hyperactivation in comparison with mTALP. When spermatozoa were exposed to $100 \mathrm{pmol} / \mathrm{l}$ serotonin after exposure to $1 \mu \mathrm{mol} / \mathrm{l}$ quipazine, hyperactivation was significantly enhanced in comparison with mTALP. However, no significant difference was seen between 'serotonin+ quipazine' and serotonin or quipazine respectively. After incubation for $2 \mathrm{~h}$ (Fig. 2D), serotonin significantly enhanced hyperactivation compared with quipazine. After incubation for $2.5,3$, and $4 \mathrm{~h}$, most motile spermatozoa were hyperactivated under all conditions (Fig. 2A). These results indicate that quipazine acts as agonist for hyperactivation.

In the next step, the dose-dependent effect of quipazine on hyperactivation was examined (Fig. 3). When quipazine concentrations between $1 \mathrm{amol} / \mathrm{l}$ and
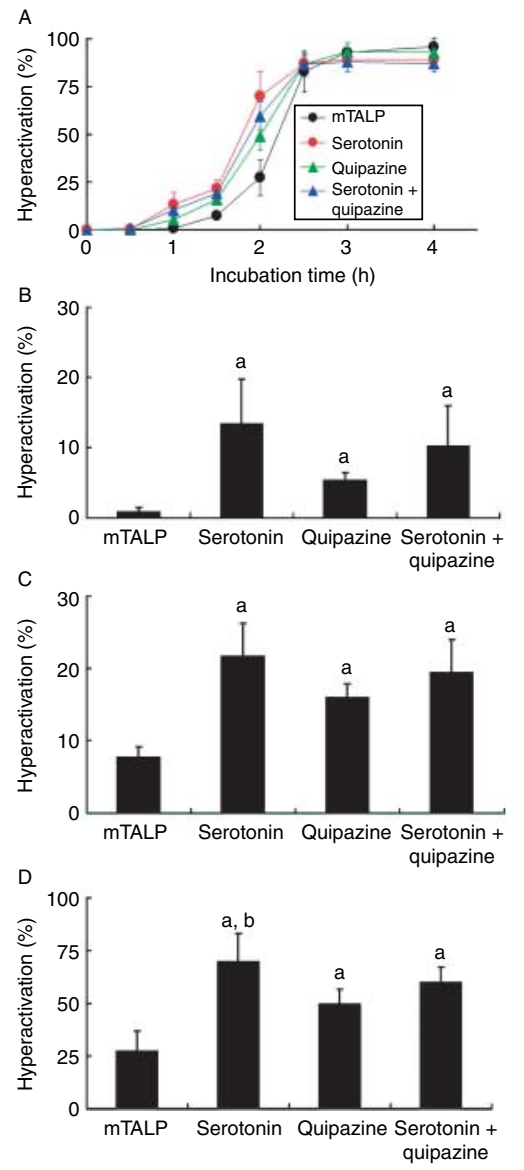

Figure 2 Effects of quipazine on serotonin-enhanced hyperactivation. The serotonin-induced AR was reportedly suppressed by quipazine (Meizel \& Turner 1983), although quipazine is a non-specific 5-HT receptor agonist. After spermatozoa were exposed to $1 \mu \mathrm{mol} / \mathrm{l}$ quipazine for $5 \mathrm{~min}$, they were exposed to $100 \mathrm{pmol} / \mathrm{l}$ serotonin. The percentage of hyperactivated spermatozoa is shown (A) as an overview of effects after incubation for (B) 1, (C) 1.5, and (D) $2 \mathrm{~h}$ when serotonin and quipazine were added to mTALP medium. Data are given as mean \pm s.D. 'mTALP', 'serotonin', 'quipazine', and 'serotonin + quipazine' indicate $\mathrm{mTALP}, \mathrm{mTALP}+100 \mathrm{pmol} / \mathrm{l}$ serotonin, $\mathrm{mTALP}$

$+1 \mu \mathrm{mol} / \mathrm{l}$ quipazine, and mTALP $+100 \mathrm{pmol} / \mathrm{l}$ serotonin $+1 \mu \mathrm{mol} / \mathrm{l}$ quipazine. ${ }^{\text {a }}$ Significant difference in comparison with mTALP.

${ }^{\mathrm{b}}$ Significant difference in comparison with quipazine.

$10 \mu \mathrm{mol} / \mathrm{l}$ were added to mTALP medium, quipazine did not affect the percentage of motile spermatozoa (data not shown), but at concentrations between $100 \mathrm{amol} / \mathrm{l}$ and $1 \mu \mathrm{mol} / \mathrm{l}$, quipazine affected the percentage of hyperactivated spermatozoa (Fig. 3A). After incubation for $0 \mathrm{~h}$, no hyperactivated spermatozoa were seen (Fig. 3A). After incubation for $0.5 \mathrm{~h}$, quipazine did not significantly enhance hyperactivation, with but a few spermatozoa hyperactivated (Fig. 3A). After incubation for $1 \mathrm{~h}$ (Fig. 3B), quipazine at a concentration of $1 \mathrm{fmol} / \mathrm{l}$ and between $1 \mathrm{pmol} / \mathrm{l}$ and $10 \mathrm{nmol} / \mathrm{l}$ significantly enhanced hyperactivation in comparison with mTALP or quipazine at $1 \mathrm{amol} / \mathrm{l}, 1 \mu \mathrm{mol} / \mathrm{l}$, or $10 \mu \mathrm{mol} / \mathrm{l}$. Quipazine at 10 and $100 \mathrm{fmol} / \mathrm{l}$ significantly enhanced hyperactivation in 
comparison with mTALP or quipazine at $1 \mathrm{amol} / \mathrm{l}$, $10 \mathrm{amol} / \mathrm{l}, 1 \mu \mathrm{mol} / \mathrm{l}$, or $10 \mu \mathrm{mol} / \mathrm{l}$. Moreover, $100 \mathrm{amol} /$ I quipazine significantly enhanced hyperactivation in comparison with mTALP or quipazine at $1 \mathrm{amol} / \mathrm{l}$ and
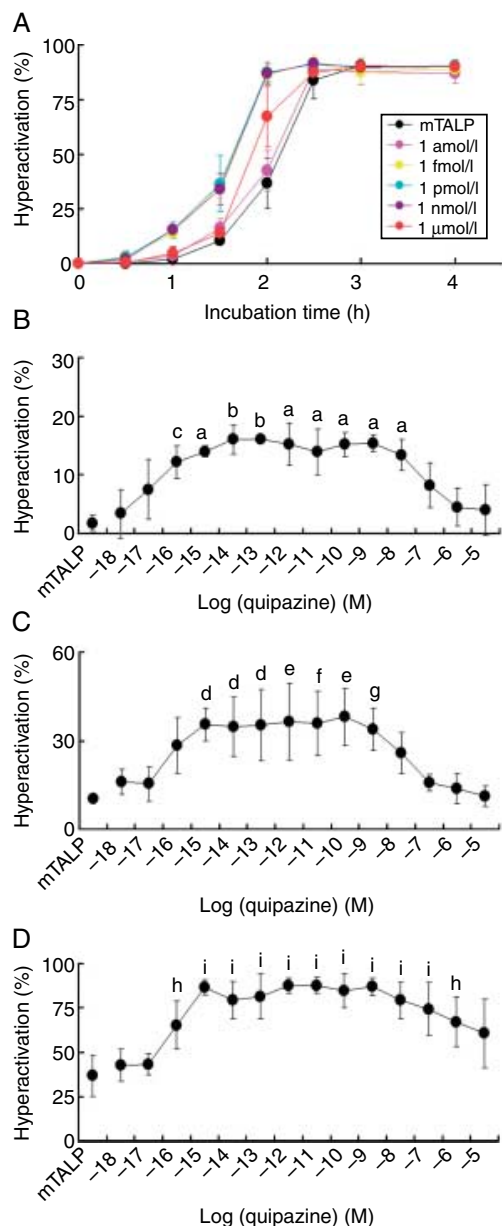

Figure 3 Dose-dependent effects of quipazine on hyperactivation. The percentage of hyperactivated spermatozoa is shown (A) as an overview of effects after incubation for (B) 1, (C) 1.5, and (D) $2 \mathrm{~h}$ after quipazine was added to mTALP medium. Data are given as mean \pm s.D. (mTALP): mTALP only; (1 amol// or -18$):$ mTALP $+1 \mathrm{amol} / \mathrm{l}$ quipazine; $(-17)$ : mTALP +10 amol/l quipazine; $(-16): \mathrm{mTALP}+100 \mathrm{amol} / \mathrm{l}$ quipazine; $(1 \mathrm{fmol} / \mathrm{l}$ or -15$): \mathrm{mTALP}+1 \mathrm{fmol} / \mathrm{l}$ quipazine; $(-14): \mathrm{mTALP}+10 \mathrm{fmol} / \mathrm{l}$ quipazine; $(-13)$ : mTALP $+100 \mathrm{fmol} / \mathrm{l}$ quipazine; $(1 \mathrm{pmol} / \mathrm{l}$ or -12$)$ : mTALP $+1 \mathrm{pmol} / \mathrm{l}$ quipazine; $(-11)$ : $\mathrm{mTALP}+10 \mathrm{pmol} / \mathrm{l}$ quipazine; $(-10)$ : $\mathrm{mTALP}+100 \mathrm{pmol} / \mathrm{l}$ quipazine; $(1 \mathrm{nmol} / \mathrm{l}$ or -9$): \mathrm{mTALP}+1 \mathrm{nmol} / \mathrm{l}$ quipazine; $(-8): \mathrm{mTALP}+10 \mathrm{nmol} / \mathrm{l}$ quipazine; $(-7)$ : mTALP

$+100 \mathrm{nmol} / \mathrm{l}$ quipazine; $(1 \mu \mathrm{mol} / \mathrm{l}$ or -6$)$ : $\mathrm{mTALP}+1 \mu \mathrm{mol} / /$ quipazine; $(-5): \mathrm{mTALP}+10 \mu \mathrm{mol} / \mathrm{l}$ quipazine. ${ }^{\mathrm{a} S i g n i f i c a n t}$ difference in comparison with mTALPor $1 \mathrm{amol} / \mathrm{l}, 1 \mu \mathrm{mol} / \mathrm{l}$, or $10 \mu \mathrm{mol} / /$ quipazine; ${ }^{\mathrm{b}}$ significant difference in comparison with mTALP or $1 \mathrm{amol} / \mathrm{l}, 10 \mathrm{amol} / \mathrm{l}, 1 \mu \mathrm{mol} / \mathrm{l}$, or $10 \mu \mathrm{mol} / \mathrm{l}$ quipazine; ${ }^{\mathrm{C}}$ significant difference in comparison with mTALP or $1 \mathrm{amol} / \mathrm{l}$ or $10 \mu \mathrm{mol} / \mathrm{l}$ quipazine; ${ }^{\mathrm{d}}$ significant difference in comparison with mTALP or $1 \mu \mathrm{mol} / \mathrm{l}$ or $10 \mu \mathrm{mol} / \mathrm{l}$ quipazine; ${ }^{\mathrm{e}}$ significant difference in comparison with mTALP or $1 \mathrm{amol} / \mathrm{l}, 10 \mathrm{amol} / \mathrm{l}, 100 \mathrm{nmol} / \mathrm{l}, 1 \mu \mathrm{mol} / \mathrm{l}$, or $10 \mu \mathrm{mol} / /$ quipazine; ${ }^{{ }}$significant difference in comparison with mTALP or $10 \mathrm{amol} / \mathrm{l}, 1 \mu \mathrm{mol} / \mathrm{l}$, or $10 \mu \mathrm{mol} / / \mathrm{l}$ quipazine; ${ }^{{ }}$significant difference in comparison with mTALP or $10 \mu \mathrm{mol} / /$ quipazine; ${ }^{\mathrm{h}}$ significant difference in comparison with mTALP; isignificant difference in comparison with $\mathrm{mTALP}$ or $1 \mathrm{amol} / \mathrm{l}$ or $10 \mathrm{amol} / \mathrm{l}$ quipazine.
$10 \mu \mathrm{mol} / \mathrm{l}$. After incubation for $1.5 \mathrm{~h}$ (Fig. 3C), quipazine at concentrations between 1 and $100 \mathrm{fmol} / /$ significantly enhanced hyperactivation in comparison with mTALP or quipazine at 1 or $10 \mu \mathrm{mol} / \mathrm{l}$. Quipazine at 1 and $100 \mathrm{pmol} / /$ significantly enhanced hyperactivation in comparison with mTALP or quipazine at concentrations of $1 \mathrm{amol} / \mathrm{l}, 10 \mathrm{amol} / \mathrm{l}$, or between $100 \mathrm{nmol} / \mathrm{l}$ and $10 \mu \mathrm{mol} / \mathrm{l}$. Quipazine at $10 \mathrm{pmol} / \mathrm{l}$ significantly enhanced hyperactivation in comparison with mTALP or quipazine at $10 \mathrm{amol} / \mathrm{l}, 1 \mu \mathrm{mol} / \mathrm{l}$, or $10 \mu \mathrm{mol} / \mathrm{l}$. Quipazine at $1 \mathrm{nmol} / \mathrm{l}$ quipazine significantly enhanced hyperactivation in comparison with mTALP or $10 \mu \mathrm{mol} / \mathrm{I}$ quipazine. Although the increase was not significant, quipazine at $100 \mathrm{amol} / \mathrm{l}$ and $10 \mathrm{nmol} / \mathrm{l}$ enhanced hyperactivation. After incubation for $2 \mathrm{~h}$ (Fig. 3D), quipazine at $100 \mathrm{amol} / \mathrm{l}$ and $1 \mu \mathrm{mol} / \mathrm{l}$ significantly enhanced hyperactivation in comparison with mTALP. Quipazine at concentrations between $1 \mathrm{fmol} / \mathrm{l}$ and $100 \mathrm{nmol} / \mathrm{l}$ significantly enhanced hyperactivation in comparison with mTALP or quipazine at 1 and $10 \mathrm{amol} /$ I. After incubation for $2.5,3$, and $4 \mathrm{~h}$, most motile spermatozoa were hyperactivated under all conditions (Fig. 3A).

Because serotonin-induced $A R$ is regulated via $5-\mathrm{HT}_{2}$ and $5-\mathrm{HT}_{4}$ receptors (Meizel \& Turner 1983), it was examined whether $5-\mathrm{HT}_{2}$ and $5-\mathrm{HT}_{4}$ receptor agonists enhanced hyperactivation (Figs 4 and 5). When $\alpha$-methylserotonin, a $5-\mathrm{HT}_{2}$ receptor agonist, was added to the MTALP medium at concentrations between $1 \mathrm{amol} / \mathrm{l}$ and $10 \mu \mathrm{mol} / \mathrm{l}$, it did not affect the percentage of motile spermatozoa (data not shown), although $\alpha$-methylserotonin at concentrations between $1 \mathrm{fmol} / \mathrm{I}$ and $100 \mathrm{pmol} / \mathrm{l}$ did affect the percentage of hyperactivated spermatozoa (Fig. 4A). At incubation for $0 \mathrm{~h}$, there were no hyperactivated spermatozoa (Fig. 4A). After incubation for $0.5 \mathrm{~h}$ (Fig. 4B), $\alpha$-methylserotonin at $1 \mathrm{fmol} / \mathrm{l}$ significantly enhanced hyperactivation in comparison with mTALP or $\boldsymbol{\alpha}$-methylserotonin at concentrations of $1 \mathrm{amol} / \mathrm{l}, 10 \mathrm{amol} / \mathrm{l}$, or between $10 \mathrm{pmol} / \mathrm{l}$ and $10 \mu \mathrm{mol} / \mathrm{l}$. $\alpha$-Methylserotonin at $10 \mathrm{fmol} / \mathrm{I}$ significantly enhanced hyperactivation in comparison with mTALP or $\alpha$-methylserotonin at concentrations of $1 \mathrm{amol} / \mathrm{l}, 10 \mathrm{amol} / \mathrm{l}$, or between $1 \mathrm{nmol} / \mathrm{l}$ and $10 \mu \mathrm{mol} / \mathrm{l}$. Moreover, $100 \mathrm{fmol} / \mathrm{l} \alpha$-methylserotonin significantly enhanced hyperactivation in comparison with mTALP or $\alpha$-methylserotonin at concentrations of $1 \mathrm{amol} / \mathrm{l}$, $10 \mathrm{amol} / \mathrm{l}$, or between $100 \mathrm{pmol} / \mathrm{l}$ and $10 \mu \mathrm{mol} / \mathrm{l}$. After incubation for $1 \mathrm{~h}$ (Fig. 4C), $\alpha$-methylserotonin at 1 and $10 \mathrm{fmol} / \mathrm{l}$ significantly enhanced hyperactivation in comparison with mTALP or $\alpha$-methylserotonin at concentrations of $1 \mathrm{amol} / \mathrm{l}, 10 \mathrm{amol} / \mathrm{l}$, or between $100 \mathrm{nmol} / \mathrm{l}$ and $10 \mu \mathrm{mol} / \mathrm{l}$. $\alpha$-Methylserotonin at $100 \mathrm{fmol} / \mathrm{I}$ significantly enhanced hyperactivation in comparison with mTALP or $1 \mathrm{amol} / \mathrm{l} \alpha$-methylserotonin. Although the increase was not significant, $\alpha$-methylserotonin at concentrations between 1 and $100 \mathrm{nmol} / \mathrm{l}$ enhanced hyperactivation. After incubation for $1.5 \mathrm{~h}$ 
(Fig. 4D), $\alpha$-methylserotonin at 1 and $10 \mathrm{fmol} / \mathrm{l}$ significantly enhanced hyperactivation in comparison with mTALP or $\boldsymbol{\alpha}$-methylserotonin at concentrations between 1 and $100 \mathrm{amol} / \mathrm{l}$ or between $100 \mathrm{pmol} / \mathrm{l}$ and $10 \mu \mathrm{mol} / \mathrm{l}$. $\alpha$-Methylserotonin at $100 \mathrm{fmol} / \mathrm{l}$ significantly enhanced hyperactivation in comparison with MTALP or $\alpha$-methylserotonin at concentrations between 1 and $100 \mathrm{amol} / \mathrm{l}$ or between $1 \mathrm{nmol} / \mathrm{l}$ and $10 \mu \mathrm{mol} / \mathrm{l}$. Moreover, $\alpha$-methylserotonin at 1 and $10 \mathrm{pmol} / \mathrm{l}$ significantly enhanced hyperactivation in comparison with mTALP or $\alpha$-methylserotonin at concentrations between $1 \mathrm{nmol} / \mathrm{I}$ and $10 \mu \mathrm{mol} / \mathrm{l}$. After incubation for $2 \mathrm{~h}$ (Fig. 4E), $\alpha$-methylserotonin at concentrations between 1 and $100 \mathrm{fmol} / \mathrm{l}$ significantly enhanced hyperactivation in comparison with mTALP or $\boldsymbol{\alpha}$-methylserotonin at concentrations of $1 \mathrm{amol} / \mathrm{l}, 10 \mathrm{amol} / \mathrm{l}$, or between $1 \mathrm{nmol} / \mathrm{l}$ and $10 \mu \mathrm{mol} / \mathrm{l}$. $\alpha$-Methylserotonin at $1 \mathrm{pmol} / \mathrm{l}$ significantly enhanced hyperactivation in comparison
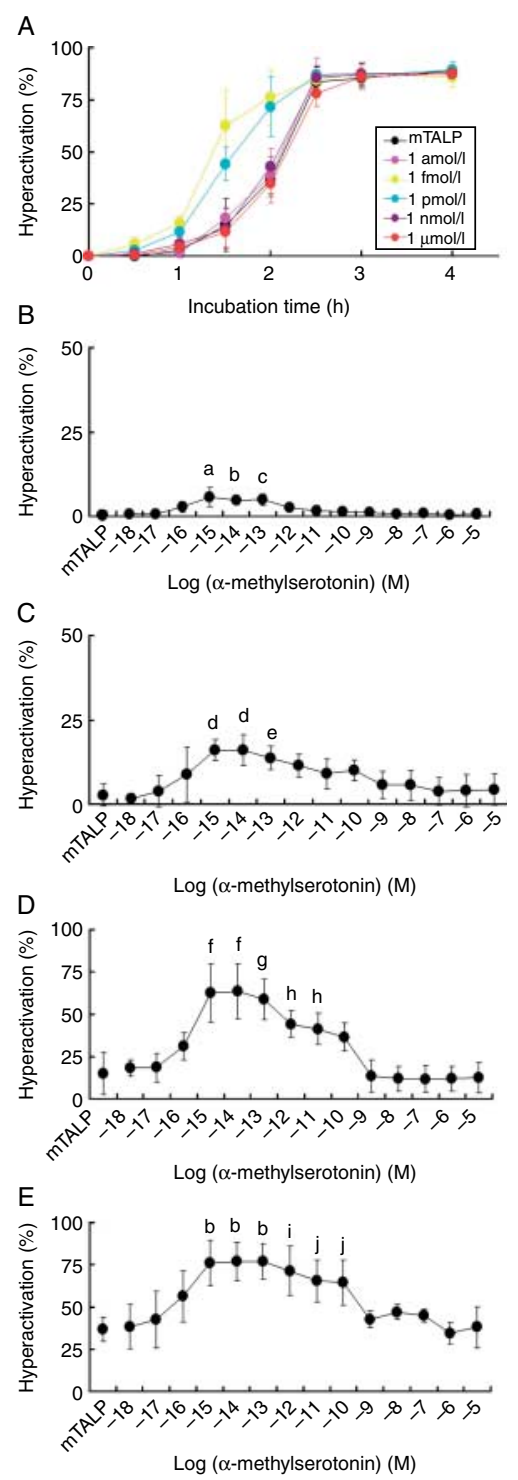

www.reproduction-online.org with mTALP or $\alpha$-methylserotonin at $1 \mathrm{amol} / \mathrm{l}, 10 \mathrm{amol} / \mathrm{l}$, $1 \mu \mathrm{mol} / \mathrm{l}$, or $10 \mu \mathrm{mol} / \mathrm{l}$. Moreover, $\alpha$-methylserotonin at 10 and $100 \mathrm{pmol} / \mathrm{I}$ significantly enhanced hyperactivation in comparison with $1 \mu \mathrm{mol} / \mathrm{l} \alpha$-methylserotonin. After incubation for 2.5, 3, and $4 \mathrm{~h}$, most motile spermatozoa were hyperactivated under all conditions (Fig. 4A).

In the next step, when 5-methoxytryptamine, a 5- $\mathrm{HT}_{4}$ receptor agonist, was added to the mTALP medium at concentrations between $1 \mathrm{amol} / \mathrm{l}$ and $10 \mu \mathrm{mol} / \mathrm{l}$, it did not affect the percentage of motile spermatozoa (data not shown), whereas 5-methoxytryptamine at concentrations between $1 \mathrm{fmol} / \mathrm{l}$ and $100 \mathrm{nmol} / \mathrm{l}$ affected the percentage of hyperactivated spermatozoa (Fig. 5A). After incubation for $0 \mathrm{~h}$, no hyperactivated spermatozoa were seen (Fig. 5A). After incubation for $0.5 \mathrm{~h}$, 5-methoxytryptamine at concentrations between $1 \mathrm{fmol} / \mathrm{l}$ and $100 \mathrm{nmol} / \mathrm{l}$ enhanced hyperactivation, although the increase was not significant (Fig. 5A). After incubation for $1 \mathrm{~h}$ (Fig. 5B), 5-methoxytryptamine at 10 and $100 \mathrm{fmol} / \mathrm{l}$ significantly enhanced hyperactivation in comparison with mTALP. Although the increase was not significant, 5-methoxytryptamine at concentrations of $1 \mathrm{fmol} / \mathrm{l}$ and between $1 \mathrm{pmol} / \mathrm{l}$ and $100 \mathrm{nmol} / \mathrm{l}$ enhanced hyperactivation. After incubation for $1.5 \mathrm{~h}$ (Fig. 5C), 5-methoxytryptamine at 1 and $10 \mathrm{fmol} / \mathrm{I}$ significantly enhanced hyperactivation in comparison with mTALP or 5-methoxytryptamine at concentrations between $1 \mathrm{amol} / \mathrm{l}$ and $100 \mathrm{amol} / \mathrm{l}$ or $1 \mu \mathrm{mol} / \mathrm{l}$ or

Figure 4 Dose-dependent effects of $\alpha$-methylserotonin on hyperactivation. The percentage of hyperactivated spermatozoa is shown $(A)$ as an overview of the effects after incubation for (B) 0.5, (C) 1, (D) 1.5, and (E) $2 \mathrm{~h}$ when $\alpha$-methylserotonin was added to mTALP medium. Data represent mean \pm s.D. (mTALP): $\mathrm{mTALP}$ only; $(1 \mathrm{amol} / \mathrm{l}$ or -18$)$ : $\mathrm{mTALP}+1 \mathrm{amol} / \mathrm{l} \alpha$-methylserotonin; $(-17): \mathrm{mTALP}+10 \mathrm{amol} / \mathrm{l}$ $\alpha$-methylserotonin; $(-16): \mathrm{mTALP}+100 \mathrm{amol} / \mathrm{l} \alpha$-methylserotonin; $(1 \mathrm{fmol} / \mathrm{l}$ or -15$)$ : mTALP $+1 \mathrm{fmol} / / \mathrm{l}$-methylserotonin; $(-14)$ : $\mathrm{mTALP}+10 \mathrm{fmol} / \mathrm{l} \alpha$-methylserotonin; $(-13): \mathrm{mTALP}+100 \mathrm{fmol} / \mathrm{l}$ $\alpha$-methylserotonin; $(1 \mathrm{pmol} / /$ or -12$)$ : $\mathrm{mTALP}+1 \mathrm{pmol} / \mathrm{l} \alpha$-methylserotonin; $(-11)$ : mTALP+10 pmol/l $\alpha$-methylserotonin; $(-10)$ : mTALP + $100 \mathrm{pmol} / \mathrm{l} \alpha$-methylserotonin; $(1 \mathrm{nmol} / \mathrm{l}$ or -9$)$ : mTALP $+1 \mathrm{nmol} / / \mathrm{l} \alpha$-methylserotonin; $(-8)$ : mTALP $+10 \mathrm{nmol} / / \mathrm{l} \alpha$-methylserotonin; (-7): mTALP $+100 \mathrm{nmol} / \mathrm{l} \alpha$-methylserotonin; $(1 \mu \mathrm{mol} / / \mathrm{l}$ or -6): $\mathrm{mTALP}+1 \mu \mathrm{mol} / \mathrm{l} \alpha$-methylserotonin; $(-5): \mathrm{mTALP}+10 \mu \mathrm{mol} / \mathrm{l}$

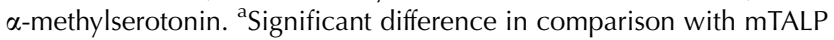
or $1 \mathrm{amol} / \mathrm{l}, 10 \mathrm{amol} / \mathrm{l}$, or between $10 \mathrm{pmol} / \mathrm{l}$ and $10 \mu \mathrm{mol} / \mathrm{l}$; ${ }^{\mathrm{b}}$ significant difference in comparison with mTALP or $1 \mathrm{amol} / \mathrm{l}$, $10 \mathrm{amol} / \mathrm{l}$, or between $1 \mathrm{nmol} / \mathrm{l}$ and $10 \mu \mathrm{mol} / \mathrm{l}$; ${ }^{\mathrm{c}}$ significant difference in comparison with mTALP or $1 \mathrm{amol} / \mathrm{l}, 10 \mathrm{amol} / \mathrm{l}$, or between $100 \mathrm{pmol} / \mathrm{l}$ and $10 \mu \mathrm{mol} / \mathrm{l}$; ${ }^{d}$ significant difference in comparison with mTALP or $1 \mathrm{amol} / \mathrm{l}, 10 \mathrm{amol} / \mathrm{l}$, or between $100 \mathrm{nmol} / \mathrm{l}$ and $10 \mu \mathrm{mol} / \mathrm{l}$; ${ }^{\text {significant }}$ difference in comparison with mTALP or $1 \mathrm{amol} / \mathrm{l}$; ${ }_{\text {significant }}$ difference in comparison with mTALP or between 1 and $100 \mathrm{amol} / \mathrm{l}$ or between $100 \mathrm{pmol} / \mathrm{l}$ and $10 \mu \mathrm{mol} / \mathrm{l}$; ${ }^{{ }}$significant difference in comparison with mTALP or between 1 and $100 \mathrm{amol} / \mathrm{l}$ or between $1 \mathrm{nmol} / \mathrm{l}$ and $10 \mu \mathrm{mol} / \mathrm{l} ;{ }^{\text {h }}$ significant difference in comparison with $\mathrm{mTALP}$ or between $1 \mathrm{nmol} / \mathrm{l}$ and $10 \mu \mathrm{mol} / \mathrm{l}$; ${ }^{i}$ significant difference in comparison with mTALP or $1 \mathrm{amol} / \mathrm{l}, 10 \mathrm{amol} / \mathrm{l}, 1 \mu \mathrm{mol} / \mathrm{l}$, or $10 \mu \mathrm{mol} / \mathrm{l}$; ${ }^{\mathrm{j}}$ significant difference in comparison with only $1 \mu \mathrm{mol} / \mathrm{l}$. 

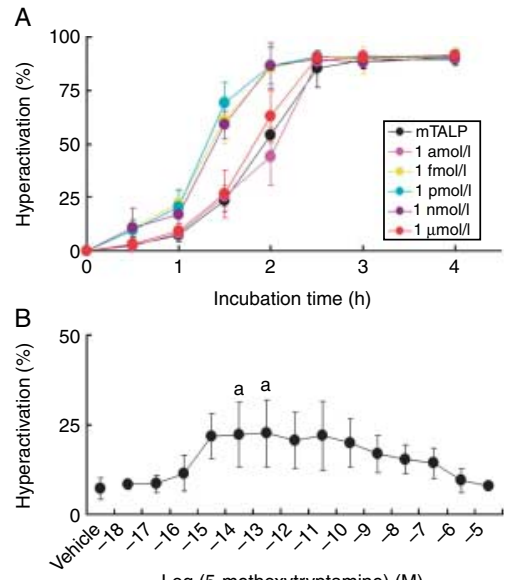

C
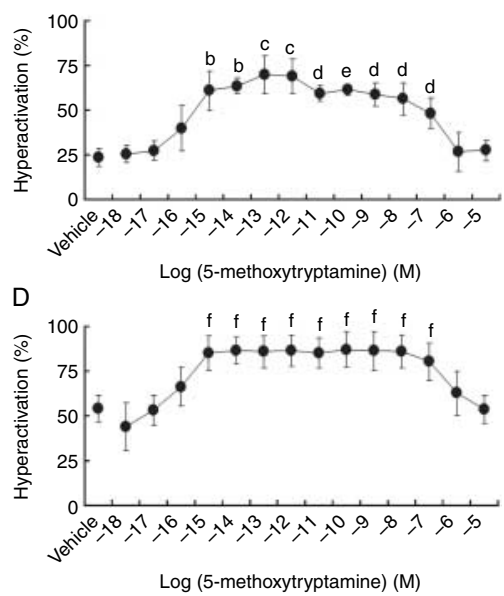

Figure 5 Dose-dependent effects of 5-methoxytryptamine on hyperactivation. The percentage of hyperactivated spermatozoa is shown (A) as an overview of effects after incubation for (B) 1, (C) 1.5, and (D) $2 \mathrm{~h}$ when 5-methoxytryptamine was added to mTALP medium. Data are given as mean \pm s.D. (Vehicle): $\mathrm{mTALP}+0.1 \% \mathrm{EtOH}(1 \mathrm{amol} / \mathrm{l}$ or -18): $\mathrm{mTALP}+1 \mathrm{amol} / \mathrm{l} 5$-methoxytryptamine $+0.1 \% \mathrm{EtOH} ;(-17)$ : $\mathrm{mTALP}+10 \mathrm{amol} / \mathrm{l}$ 5-methoxytryptamine $+0.1 \% \mathrm{EtOH} ;(-16)$ : $\mathrm{mTALP}+100 \mathrm{amol} / \mathrm{l} 5$-methoxytryptamine $+0.1 \% \mathrm{EtOH} ;(1 \mathrm{fmol} / \mathrm{l}$ or -15): $\mathrm{mTALP}+1 \mathrm{fmol} / \mathrm{l}$ 5-methoxytryptamine $+0.1 \% \mathrm{EtOH} ;(-14)$ : $\mathrm{mTALP}+10 \mathrm{fmol} / \mathrm{l}$ 5-methoxytryptamine $+0.1 \% \mathrm{EtOH} ;(-13)$ : $\mathrm{mTALP}+100 \mathrm{fmol} / \mathrm{l} 5$-methoxytryptamine $+0.1 \% \mathrm{EtOH} ;(1 \mathrm{pmol} / \mathrm{l}$ or -12): $\mathrm{mTALP}+1 \mathrm{pmol} / \mathrm{l}$ 5-methoxytryptamine $+0.1 \% \mathrm{EtOH} ;(-11)$ : $\mathrm{mTALP}+10 \mathrm{pmol} / \mathrm{l} 5$-methoxytryptamine $+0.1 \% \mathrm{EtOH} ;(-10)$ : $\mathrm{mTALP}+100 \mathrm{pmol} / \mathrm{l} 5$-methoxytryptamine $+0.1 \% \mathrm{EtOH} ;(1 \mathrm{nmol} / \mathrm{l}$ or -9): $\mathrm{mTALP}+1 \mathrm{nmol} / \mathrm{l} 5$-methoxytryptamine $+0.1 \% \mathrm{EtOH} ;(-8)$ : $\mathrm{mTALP}+10 \mathrm{nmol} / \mathrm{l}$ 5-methoxytryptamine $+0.1 \% \mathrm{EtOH} ;(-7)$ : $\mathrm{mTALP}+100 \mathrm{nmol} / \mathrm{l} 5$-methoxytryptamine $+0.1 \% \mathrm{EtOH} ;(1 \mu \mathrm{mol} / \mathrm{l}$ or -6): $\mathrm{mTALP}+1 \mu \mathrm{mol} / \mathrm{l} 5$-methoxytryptamine $+0.1 \% \mathrm{EtOH} ;(-5)$ : $\mathrm{mTALP}+10 \mu \mathrm{mol} / \mathrm{I} 5$-methoxytryptamine $+0.1 \% \mathrm{EtOH}$. ${ }^{\mathrm{a}}$ Significant difference in comparison with mTALP; ${ }^{b}$ significant difference in comparison with mTALP or between $1 \mathrm{amol} / \mathrm{l}$ and $100 \mathrm{amol} / \mathrm{l}, 1 \mu \mathrm{mol} / \mathrm{l}$, or $10 \mu \mathrm{mol} / \mathrm{l}$; ${ }^{\mathrm{c}}$ significant difference in comparison with mTALP or between 1 and $100 \mathrm{amol} / \mathrm{l}$ or between $100 \mathrm{nmol} / \mathrm{l}$ and $10 \mu \mathrm{mol} / /$;

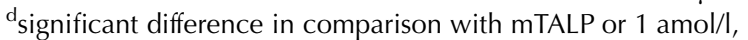

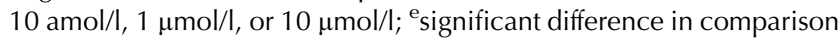
with mTALP or between $1 \mathrm{amol} / \mathrm{l}$ and $100 \mathrm{amol} / \mathrm{l}, 1 \mu \mathrm{mol} / \mathrm{l}$, or $10 \mu \mathrm{mol} / /$; ${ }^{\mathrm{f}}$ significant difference in comparison with mTALP or $1 \mathrm{amol} / \mathrm{l}, 10 \mathrm{amol} / \mathrm{l}$, or $10 \mu \mathrm{mol} / \mathrm{l}$.
$10 \mu \mathrm{mol} / \mathrm{l}$. 5-Methoxytryptamine at $100 \mathrm{fmol} / \mathrm{l}$ and $1 \mathrm{pmol} / \mathrm{I}$ significantly enhanced hyperactivation in comparison with mTALP or 5-methoxytryptamine at concentrations between 1 and $100 \mathrm{amol} / \mathrm{l}$ or between $100 \mathrm{nmol} / \mathrm{l}$ and $10 \mu \mathrm{mol} / \mathrm{l}$ 5-methoxytryptamine. 5-Methoxytryptamine at concentrations of $10 \mathrm{pmol} / \mathrm{l}$ and between 1 and $100 \mathrm{nmol} / \mathrm{l}$ significantly enhanced hyperactivation in comparison with mTALP or 5-methoxytryptamine at $1 \mathrm{amol} / \mathrm{l}, 10 \mathrm{amol} / \mathrm{l}, 1 \mu \mathrm{mol} / \mathrm{l}$, or $10 \mu \mathrm{mol} / \mathrm{l}$. 5-Methoxytryptamine at $100 \mathrm{pmol} / \mathrm{l}$ significantly enhanced hyperactivation in comparison with mTALP or 5-methoxytryptamine at concentrations between $1 \mathrm{amol} / \mathrm{l}$ and $100 \mathrm{amol} / \mathrm{l}$ or $1 \mu \mathrm{mol} / \mathrm{l}$ or $10 \mu \mathrm{mol} / \mathrm{l}$ 5-methoxytryptamine. After incubation for $2 \mathrm{~h}$ (Fig. 5D), 5-methoxytryptamine at concentrations between $1 \mathrm{fmol} / \mathrm{l}$ and $100 \mathrm{nmol} / \mathrm{l}$ significantly enhanced hyperactivation in comparison with mTALP or 5 -methoxytryptamine at $1 \mathrm{amol} / \mathrm{l}, 10 \mathrm{amol} / \mathrm{l}$, or $10 \mu \mathrm{mol} / \mathrm{l}$. After incubation for $2.5,3$, and $4 \mathrm{~h}$, most motile spermatozoa were hyperactivated under all conditions (Fig. 5A).

\section{Effects of 5-HT receptor antagonists on serotonin- enhanced hyperactivation}

As both the $5-\mathrm{HT}_{2}$ receptor agonist ( $\alpha$-methylserotonin) and the $5-\mathrm{HT}_{4}$ receptor agonist (5-methoxytryptamine) enhanced sperm hyperactivation, it was examined whether a $5-\mathrm{HT}_{2}$ receptor antagonist (cyproheptadine) and $5-\mathrm{HT}_{4}$ receptor antagonist (GR113808) suppressed serotonin-enhanced and agonist-enhanced hyperactivation.

Cyproheptadine at $1 \mu \mathrm{mol} / /$ significantly suppressed serotonin-enhanced (Fig. 6A), quipazine-enhanced (Fig. 6C), and $\alpha$-methylserotonin-enhanced hyperactivation (Fig. 7A), although it did not affect the percentages of motile (data not shown) or hyperactivated spermatozoa (Figs 6 and 7), or of 5-methoxytryptamine-enhanced hyperactivation (Fig. 7B). Cyproheptadine significantly suppressed serotonin-enhanced and quipazineenhanced hyperactivation when spermatozoa were exposed to $100 \mathrm{pmol} / \mathrm{l}$ serotonin or $100 \mathrm{pmol} / \mathrm{l}$ quipazine, the respective average effective concentrations, after exposure to $1 \mu \mathrm{mol} / \mathrm{l}$ cyproheptadine for $5 \mathrm{~min}$ (Fig. 6A and C). However, cyproheptadine did not suppress serotonin-enhanced and quipazine-enhanced hyperactivation when spermatozoa were exposed to $100 \mathrm{nmol} / \mathrm{l}$ serotonin and $100 \mathrm{nmol} / \mathrm{l}$ quipazine, the respective maximum effective concentrations, after exposure to $1 \mu \mathrm{mol} / \mathrm{l}$ cyproheptadine for $5 \mathrm{~min}$ (Fig. $6 \mathrm{~B}$ and D). When spermatozoa were exposed to $100 \mathrm{fmol} / \mathrm{l}$ $\alpha$-methylserotonin, the average effective concentration, after exposure to $1 \mu \mathrm{mol} / \mathrm{l}$ cyproheptadine for $5 \mathrm{~min}$, cyproheptadine significantly suppressed $\alpha$-methylserotonin-enhanced hyperactivation (Fig. 7A). However, 5-methoxytryptamine-enhanced hyperactivation was not suppressed by cyproheptadine when spermatozoa 

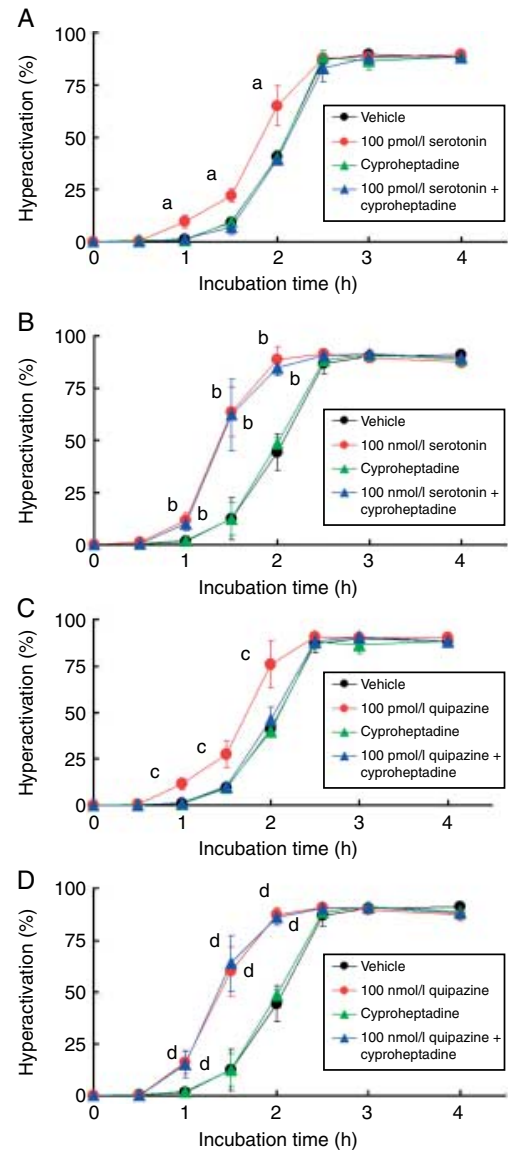

Figure 6 Effects of cyproheptadine on serotonin-enhanced and quipazineenhanced hyperactivation. After spermatozoa were exposed to cyproheptadine for $5 \mathrm{~min}$, they were exposed to serotonin or quipazine. The percentages of hyperactivated spermatozoa (A-D) are shown when $100 \mathrm{pmol} / \mathrm{l}$ serotonin, $100 \mathrm{nmol} / \mathrm{l}$ serotonin, $100 \mathrm{pmol} / \mathrm{l}$ quipazine, $100 \mathrm{nmol} / \mathrm{l}$ quipazine, and $1 \mu \mathrm{mol} / / \mathrm{l}$ cyproheptadine were added to mTALP medium. Data are given as mean \pm s.D. In (A), 'vehicle', '100 pmol// serotonin', 'cyproheptadine', and '100 pmol/l serotonin + cyproheptadine' indicate $\mathrm{mTALP}+0.1 \% \mathrm{MeOH}, \mathrm{mTALP}+100 \mathrm{pmol} / \mathrm{l}$ serotonin $+0.1 \%$ $\mathrm{MeOH}, \mathrm{mTALP}+1 \mu \mathrm{mol} / \mathrm{l}$ cyproheptadine $+0.1 \% \mathrm{MeOH}$ and mTALP $+100 \mathrm{pmol} / \mathrm{l}$ serotonin $+1 \mu \mathrm{mol} / \mathrm{l}$ cyproheptadine $+0.1 \% \mathrm{MeOH}$. In (B), 'vehicle', '100 nmol// serotonin', 'cyproheptadine', and '100 nmol// serotonin + cyproheptadine' indicate mTALP $+0.1 \% \mathrm{MeOH}$, mTALP $+100 \mathrm{nmol} / \mathrm{l}$ serotonin $+0.1 \% \mathrm{MeOH}, \mathrm{mTALP}+1 \mu \mathrm{mol} / / \mathrm{l}$ cyproheptadine $+0.1 \% \mathrm{MeOH}$ and $\mathrm{mTALP}+100 \mathrm{nmol} / \mathrm{l}$ serotonin $+1 \mu \mathrm{mol} / / \mathrm{l}$ cyproheptadine $+0.1 \% \mathrm{MeOH}$. In $(\mathrm{C})$, 'vehicle', '100 pmol/l quipazine', 'cyproheptadine', and '100 pmol// quipazine + cyproheptadine' indicate $\mathrm{mTALP}+0.1 \% \mathrm{MeOH}, \mathrm{mTALP}+100 \mathrm{pmol} / \mathrm{l}$ quipazine $+0.1 \% \mathrm{MeOH}$, $\mathrm{mTALP}+1 \mu \mathrm{mol} / \mathrm{l}$ cyproheptadine $+0.1 \% \mathrm{MeOH}$ and $\mathrm{mTALP}+$ $100 \mathrm{pmol} / \mathrm{l}$ quipazine $+1 \mu \mathrm{mol} / \mathrm{l}$ cyproheptadine $+0.1 \% \mathrm{MeOH}$. In (D), 'vehicle', '100 nmol// quipazine', 'cyproheptadine', and '100 nmol/l quipazine + cyproheptadine' indicate mTALP $+0.1 \% \mathrm{MeOH}$, mTALP $+100 \mathrm{nmol} / \mathrm{l}$ quipazine $+0.1 \% \mathrm{MeOH}, \mathrm{mTALP}+1 \mu \mathrm{mol} / \mathrm{l}$ cyproheptadi$\mathrm{ne}+0.1 \% \mathrm{MeOH}$ and $\mathrm{mTALP}+100 \mathrm{nmol} / \mathrm{l}$ quipazine $+1 \mu \mathrm{mol} / \mathrm{l}$ cyproheptadine $+0.1 \% \mathrm{MeOH}$. ${ }^{\mathrm{a}}$ Significant difference in comparison with 'vehicle' or 'cyproheptadine' or '100 pmol/l serotonin + cyproheptadine'. ${ }^{\mathrm{b}}$ Significant difference in comparison with 'vehicle' or 'cyproheptadine' or '100 nmol// serotonin + cyproheptadine'. 'Significant difference in comparison with 'vehicle' or 'cyproheptadine' or ' $100 \mathrm{pmol} / \mathrm{l}$ quipazine + cyproheptadine'. ${ }^{\mathrm{d}}$ Significant difference in comparison with 'vehicle' or 'cyproheptadine' or '100 nmol/l quipazine + cyproheptadine'. were exposed to $10 \mathrm{pmol} / \mathrm{l}$ 5-methoxytryptamine, the average effective concentration, after exposure to $1 \mu \mathrm{mol} / \mathrm{l}$ cyproheptadine for $5 \mathrm{~min}$ (Fig. 7B).

GR113808 at $1 \mu \mathrm{mol} / \mathrm{l}$ also significantly suppressed serotonin-enhanced (Fig. 8A), quipazine-enhanced (Fig. 8C), and 5-methoxytryptamine-enhanced hyperactivation (Fig. 9B), although GR113808 did not affect the percentages of motile (data not shown) or hyperactivated spermatozoa (Figs 8 and 9). GR113808 significantly suppressed serotonin-enhanced and quipazineenhanced hyperactivation when spermatozoa were exposed to $100 \mathrm{nmol} / \mathrm{l}$ serotonin and $100 \mathrm{nmol} / \mathrm{l}$ quipazine after exposure to $1 \mu \mathrm{mol} / \mathrm{l} \mathrm{GR} 113808$ for $5 \mathrm{~min}$ (Fig. 8A and C). When spermatozoa were exposed to $100 \mathrm{pmol} / \mathrm{l}$ serotonin and $100 \mathrm{pmol} / \mathrm{l}$ quipazine after exposure to $1 \mu \mathrm{mol} / / \mathrm{GR} 113808$ for $5 \mathrm{~min}$, however, GR113808 did not suppress serotonin-enhanced and quipazine-enhanced hyperactivation (Fig. 8B and D). When spermatozoa were exposed to $100 \mathrm{fmol} / \mathrm{I}$ $\alpha$-methylserotonin after exposure to $1 \mu \mathrm{mol} / \mathrm{l} \mathrm{GR} 113808$ for $5 \mathrm{~min}, \alpha$-methylserotonin-enhanced hyperactivation was not suppressed by GR113808 (Fig. 9A). However, 5-methoxytryptamine-enhanced hyperactivation was suppressed by $1 \mu \mathrm{mol} / \mathrm{l}$ GR113808 when spermatozoa were exposed to $10 \mathrm{pmol} / \mathrm{l}$ 5-methoxytryptamine after

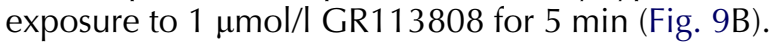

\section{Effects of $\mathrm{Ca}^{2+}$ and albumin on hyperactivation}

Progesterone and melatonin significantly enhance hyperactivation, although they are not associated with the spontaneous regulatory mechanisms of hyperactivation (Fujinoki 2008, Noguchi et al. 2008). Accordingly, it was examined whether serotonin-enhanced hyperactivation is associated with the spontaneous regulatory mechanisms of hyperactivation.

As shown in Fig. 10A, the percentage of motile spermatozoa was significantly decreased after incubation for $1 \mathrm{~h}$ in mTALP medium without $\mathrm{Ca}^{2+}$, and after incubation for $2.5,3$, or $4 \mathrm{~h}$, most spermatozoa were not motile. Serotonin did not affect the percentage of motile spermatozoa in mTALP medium without $\mathrm{Ca}^{2+}$. Spermatozoa were not hyperactivated in mTALP medium without $\mathrm{Ca}^{2+}$, even if serotonin was added (Fig. 10B).

In mTALP medium without BSA, most spermatozoa were not hyperactivated even if serotonin was added (Fig. 10C). However, the addition of BSA did not affect the percentage of motile spermatozoa (data not shown).

\section{Discussion}

Recent studies have been suggested that hyperactivation is regulated in a ligand-dependent manner, with ligands including progesterone, $17 \beta$-estradiol, and melatonin (Sueldo et al. 1993, Yang et al. 1994, Fujinoki 

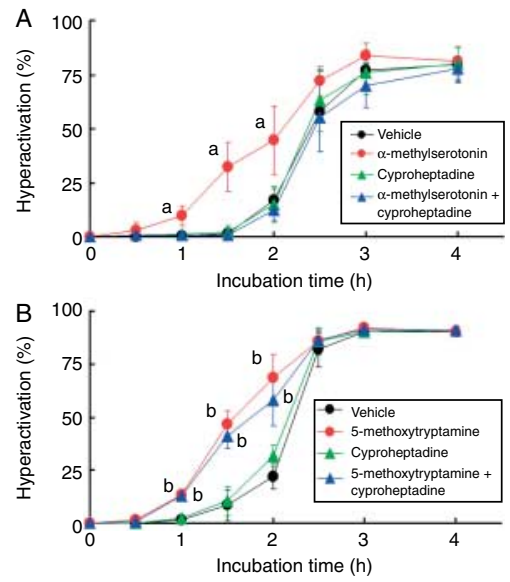

Figure 7 Effects of cyproheptadine on $\alpha$-methylserotonin-enhanced and 5-methoxytryptamine-enhanced hyperactivation. After spermatozoa were exposed to cyproheptadine for $5 \mathrm{~min}$, they were exposed to $\alpha$-methylserotonin or 5 -methoxytryptamine. The percentages of hyperactivated spermatozoa (A and B) are shown when $100 \mathrm{fmol} / \mathrm{I}$ $\alpha$-methylserotonin, $10 \mathrm{pmol} / \mathrm{l} 5$-methoxytryptamine, and $1 \mu \mathrm{mol} / \mathrm{l}$ cyproheptadine were added to mTALP medium. Data are given as mean \pm s.D. In (A), 'vehicle', ' $\boldsymbol{\alpha}$-methylserotonin', 'cyproheptadine', and ' $\alpha$-methylserotonin + cyproheptadine' indicate mTALP $+0.1 \%$ $\mathrm{MeOH}, \mathrm{mTALP}+100 \mathrm{fmol} / \mathrm{l} \alpha$-methylserotonin, $+0.1 \% \mathrm{MeOH}$, $\mathrm{mTALP}+1 \mu \mathrm{mol} / \mathrm{l}$ cyproheptadine $+0.1 \% \mathrm{MeOH}$ and $\mathrm{mTALP}$ $+100 \mathrm{fmol} / / \mathrm{l} \alpha$-methylserotonin, $+1 \mu \mathrm{mol} / / \mathrm{l}$ cyproheptadine $+0.1 \%$ $\mathrm{MeOH} . \operatorname{In}(\mathrm{B})$, 'vehicle', '5-methoxytryptamine', 'cyproheptadine', and '5-methoxytryptamine + cyproheptadine' indicate mTALP + 0.1\% $\mathrm{MeOH}+0.1 \% \mathrm{EtOH}, \mathrm{mTALP}+10 \mathrm{pmol} / \mathrm{l} 5$-methoxytryptamine $+0.1 \% \mathrm{MeOH}+0.1 \% \mathrm{EtOH}, \mathrm{mTALP}+1 \mu \mathrm{mol} / \mathrm{l}$ cyproheptadine $+0.1 \%$ $\mathrm{MeOH}+0.1 \% \mathrm{EtOH}$ and mTALP $+10 \mathrm{pmol} / \mathrm{l} 5$-methoxytryptamine $+1 \mu \mathrm{mol} / \mathrm{l}$ cyproheptadine $+0.1 \% \mathrm{MeOH}+0.1 \% \mathrm{EtOH}$. ${ }^{\mathrm{a}}$ Significant difference in comparison with 'vehicle' or 'cyproheptadine' or ' $\alpha$-methylserotonin + cyproheptadine'. 'bignificant difference in comparison with 'vehicle' or 'cyproheptadine' or '5-methoxytryptamine+ cyproheptadine'.

2008, 2010, Noguchi et al. 2008, du Plessis et al. 2010). Those ligands are also associated with regulation of the AR (Osman et al. 1989, Luconi et al. 2004, Baldi et al. 2009, Casao et al. 2009).

In this study, it was examined whether serotonin and its agonists are associated with regulation of hyperactivation, because a previous study (Meizel \& Turner 1983) demonstrated that serotonin and its agonists induce the $A R$ in hamster spermatozoa. Serotonin and quipazine significantly enhanced hyperactivation in a dose-dependent manner (see Figs 1-3). For hamster spermatozoa, the effective concentration ranges of serotonin and quipazine were $1 \mathrm{fmol} / \mathrm{l}$ to $1 \mu \mathrm{mol} / \mathrm{l}$ and $100 \mathrm{amol} / \mathrm{l}$ to $1 \mu \mathrm{mol} / \mathrm{l}$ respectively. As the effective concentration range of melatonin for enhancement of hyperactivation is $1 \mathrm{pmol} / \mathrm{l}$ to $1 \mu \mathrm{mol} / \mathrm{l}$ (Fujinoki 2008), serotonin is more potent than melatonin. In general, the actions of serotonin are mediated by 5-HT receptors (Noda et al. 2004, Ganong 2005). A previous study (Meizel \& Turner 1983) demonstrated that serotonin and 5-methoxytryptamine induce the $A R$ and that both serotonin-induced and 5-methoxytryptamine-induced AR are inhibited by cyproheptadine. Therefore, it is likely that serotonin induces the $A R$ via $5-\mathrm{HT}_{2}$ and $5-\mathrm{HT}_{4}$ receptors. Both $\alpha$-methylserotonin and 5-methoxytryptamine significantly enhanced sperm hyperactivation in a dose-dependent manner (see Figs 4 and 5). The effective concentration ranges of $\alpha$-methylserotonin and 5-methoxytryptamine were $1 \mathrm{fmol} / \mathrm{l}$ to $100 \mathrm{pmol} / \mathrm{l}$ and $1 \mathrm{fmol} / \mathrm{l}$ to $100 \mathrm{nmol} / \mathrm{l}$ respectively. Moreover, cyproheptadine and GR113808 suppressed $\alpha$-methylserotonin-enhanced and 5-methoxytryptamine-enhanced hyperactivation respectively (see Figs 7 and 9). Interestingly, enhancement of hyperactivation by $100 \mathrm{pmol} / \mathrm{l}$ serotonin and $100 \mathrm{pmol} / \mathrm{I}$ quipazine were significantly suppressed by cyproheptadine (see Fig. 6A and C), although enhancement of hyperactivation by $100 \mathrm{nmol} / \mathrm{l}$ serotonin and $100 \mathrm{nmol} / \mathrm{l}$ quipazine were not suppressed by cyproheptadine (see Fig. 6B and D). However, enhancement of hyperactivation by $100 \mathrm{nmol} / /$ serotonin and $100 \mathrm{nmol} / /$ quipazine were significantly suppressed by GR113808 (see Fig. 8A and $\mathrm{C}$ ), whereas enhancement of hyperactivation by $100 \mathrm{pmol} / \mathrm{l}$ serotonin and $100 \mathrm{pmol} / \mathrm{l}$ quipazine were not suppressed by GR113808 (see Fig. 8B and D). These results suggest that serotonin enhances hyperactivation via the $5-\mathrm{HT}_{2}$ and $5-\mathrm{HT}_{4}$ receptors in a dose-dependent manner.

Generally, 5- $\mathrm{HT}_{2}$ receptor and $5-\mathrm{HT}_{4}$ receptors are activated by PLC and AC respectively (Noda et al. 2004, Ganong 2005). Activation of PLC induces production of inositol 1,4,5-tris-phosphate $\left(\mathrm{IP}_{3}\right)$ and diacylglycerol, increases intracellular $\mathrm{Ca}^{2+}$, and activates protein kinase C. In mammalian spermatozoa, PLC is associated with the regulation of progesteroneinduced AR and progesterone-enhanced hyperactivation (Luconi et al. 2004, Noguchi et al. 2008, Baldi et al. 2009, Fujinoki 2009). It has been suggested that $\mathrm{IP}_{3}$ is also associated with regulation of hyperactivation (Ho \& Suarez 2001). Because serotonin-enhanced hyperactivation was regulated via $5-\mathrm{HT}_{2}$ receptors (see Figs 4, 6 and 7), it is likely that $100 \mathrm{pmol} / \mathrm{l}$ serotonin and $\alpha$-methylserotonin enhance hyperactivation through $5-\mathrm{HT}_{2}$ receptors and $\mathrm{PLC}-\mathrm{IP}$ signals. In progesterone-enhanced hyperactivation, tyrosine phosphorylation of sperm proteins is enhanced and increased after activation of PLC (Noguchi et al. 2008, Fujinoki 2009, 2010). Although it is not clear whether serotonin enhances and increases tyrosine phosphorylation of sperm proteins together with enhancement of hyperactivation, it is my understanding that tyrosine phosphorylation is enhanced and increased when serotonin enhances hyperactivation. However, serotonin also enhanced hyperactivation via $5-\mathrm{HT}_{4}$ receptors (see Figs 5, 8 and 9). As 5- $\mathrm{HT}_{4}$ receptor induces activation of $\mathrm{AC}$ and CAMP production, it is likely that $100 \mathrm{nmol} / \mathrm{l}$ serotonin and 5-methoxytryptamine enhance hyperactivation through 

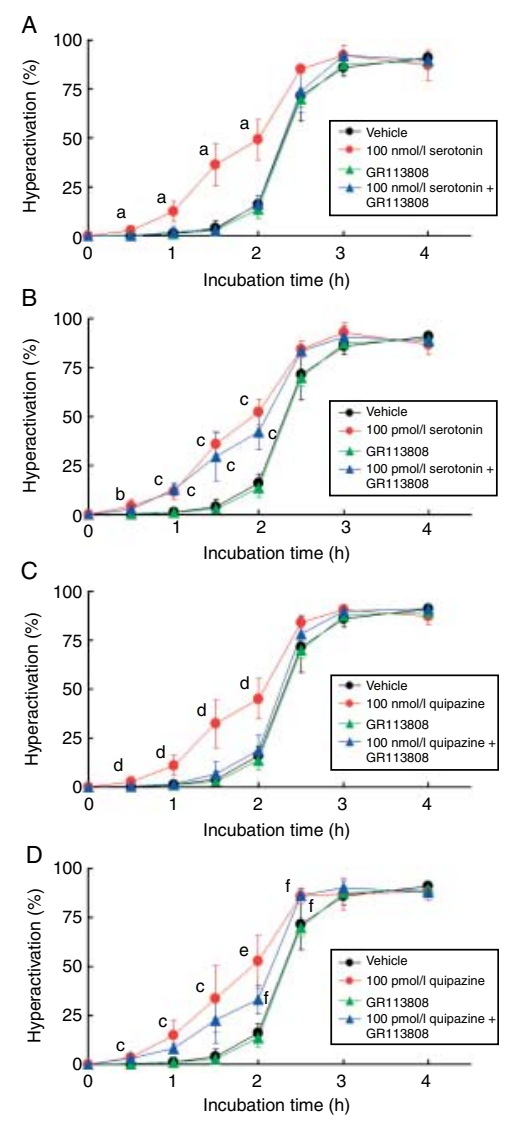

Figure 8 Effects of GR113808 on serotonin-enhanced and quipazineenhanced hyperactivation. After spermatozoa were exposed to GR113808 for $5 \mathrm{~min}$, they were exposed to serotonin or quipazine. The percentages of hyperactivated spermatozoa $(\mathrm{A}-\mathrm{D})$ are shown when $100 \mathrm{nmol} / \mathrm{l}$ serotonin, $100 \mathrm{pmol} / / \mathrm{l}$ serotonin, $100 \mathrm{nmol} / \mathrm{l}$ quipazine, $100 \mathrm{pmol} / \mathrm{l}$ quipazine, and $1 \mu \mathrm{mol} / \mathrm{l}$ GR113808 were added to mTALP medium. Data are given as mean \pm s.D. In (A), 'vehicle', '100 nmol// serotonin', 'GR113808', and '100 nmol/l serotonin + GR113808' indicate $\mathrm{mTALP}+0.1 \% \mathrm{DMSO}, \mathrm{mTALP}+100 \mathrm{nmol} / \mathrm{l}$ serotonin $+0.1 \%$ DMSO, mTALP $+1 \mu \mathrm{mol} / \mathrm{l} \mathrm{GR} 113808+0.1 \% \mathrm{DMSO}$, and mTALP $+100 \mathrm{nmol} / \mathrm{l}$ serotonin $+1 \mu \mathrm{mol} / \mathrm{l} \mathrm{GR} 113808+0.1 \%$ DMSO. In (B), 'vehicle', '100 pmol// serotonin', 'GR113808', and '100 pmol// serotonin + GR113808' indicate mTALP + 0.1\% DMSO, mTALP $+100 \mathrm{pmol} / \mathrm{l}$ serotonin $+0.1 \% \mathrm{DMSO}, \mathrm{mTALP}+1 \mu \mathrm{mol} / \mathrm{l}$ GR113808+0.1\% DMSO, and mTALP + $100 \mathrm{pmol} / \mathrm{l}$ serotonin $+1 \mu \mathrm{mol} / \mathrm{l}$ GR113808 + 0.1\% DMSO. In (C), 'vehicle', '100 nmol/l quipazine', 'GR113808', and '100 nmol/l quipazine+ GR113808' indicate $\mathrm{mTALP}+0.1 \% \mathrm{DMSO}, \mathrm{mTALP}+100 \mathrm{nmol} / \mathrm{l}$ quipazine $+0.1 \%$ DMSO, mTALP $+1 \mu \mathrm{mol} / \mathrm{l} \mathrm{GR} 113808+0.1 \%$ DMSO, and mTALP + $100 \mathrm{nmol} / \mathrm{l}$ quipazine $+1 \mu \mathrm{mol} / \mathrm{l}$ GR113808+0.1\% DMSO. In (D), 'vehicle', '100 pmol/l quipazine', 'GR113808', and '100 pmol/l quipazine + GR113808' indicate mTALP + 0.1\% DMSO, mTALP $+100 \mathrm{pmol} / \mathrm{l}$ quipazine $+0.1 \% \mathrm{DMSO}, \mathrm{mTALP}+1 \mu \mathrm{mol} / \mathrm{l} \mathrm{GR} 113808$ $+0.1 \%$ DMSO, and mTALP $+100 \mathrm{pmol} / \mathrm{l}$ quipazine $+1 \mu \mathrm{mol} / \mathrm{l}$ GR113808+0.1\% DMSO. ${ }^{a}$ Significant difference in comparison with 'vehicle' or 'GR113808' or '100 nmol/l serotonin + GR113808'. bSignificant difference in comparison with 'vehicle'. 'Significant difference in comparison with 'vehicle' or 'GR113808'. 'Significant difference in comparison with 'vehicle' or 'GR113808' or '100 nmol/l quipazine + GR113808'. ' Significant difference in comparison with 'vehicle' or 'GR113808' or '100 pmol/l quipazine+GR113808'. 'Significant difference in comparison with 'GR113808'.
5- $\mathrm{HT}_{4}$ receptors and AC-cAMP signals. In general, hyperactivation is regulated by CAMP-PKA signals (Yanagimachi 1994, Visconti et al. 1995). In addition, tyrosine phosphorylation is also regulated by CAMP/ PKA signals (Visconti et al. 1995, 1999, Fujinoki et al. 2006). Therefore, it is reasonable to assume that serotonin also enhances and increases tyrosine phosphorylation together with hyperactivation through $5-\mathrm{HT}_{4}$ receptors and AC-cAMP-PKA signals.

Progesterone-enhanced and melatonin-enhanced hyperactivation are not associated with the spontaneous regulatory mechanisms, because these enhancements only occur in complete media in which spermatozoa can be hyperactivated (Fujinoki 2008, Noguchi et al. 2008). Serotonin-enhanced hyperactivation also occurred in the complete medium in which spermatozoa could be hyperactivated and did not occur in media without $\mathrm{Ca}^{2+}$ or albumin (see Fig. 10). Therefore, it is likely that serotonin-enhanced hyperactivation also occurs through a modulatory mechanism, as with progesteroneenhanced and melatonin-enhanced hyperactivation.

Serotonin and 5-HT receptors are found in oocytes, COC, follicular fluid, and embryos in mammals (Dubé \& Amireault 2007). The serotonin content in the rat oviduct ranged from 2.06 to $3.34 \mu \mathrm{g} / \mathrm{g}$ fresh tissue (Juorio et al. 1989). In human, serotonin in the preovulatory follicles and the cystically degenerated follicles were $14.3 \pm 8.9$ and $12.2 \pm 6.2 \mu \mathrm{g} / 100 \mathrm{ml}$ respectively (Bódis et al. 1992). In the female reproductive organs, serotonin is mainly released from cumulus cells and is associated with the regulation of steroidogenesis and oocyte maturation (Dubé \& Amireault 2007). Serotonin at $100 \mathrm{pmol} / \mathrm{l}$ induced progesterone released from human granulose cells (Bódis et al. 1993). The results of a previous study (Meizel \& Turner 1983) and this study both suggest that serotonin directly induces the AR and enhances hyperactivation. The effective concentrations of serotonin to induce the AR and to enhance hyperactivation are several $\mu \mathrm{mol} / \mathrm{l}$ and between $1 \mathrm{fmol} / \mathrm{I}$ and $1 \mu \mathrm{mol} / \mathrm{l}$ respectively (Meizel \& Turner 1983, see Fig. 1). The AR occurs near or at oocytes and the COC. In contrast, hyperactivation occurs at a distance from oocytes and the COC. Therefore, it is likely that serotonin regulates sperm functions depending on the distance between the spermatozoa and the oocytes. Spermatozoa have various systems to regulate sperm functions depending on the distance between spermatozoa and oocytes. Progesterone enhances hyperactivation (Noguchi et al. 2008, Fujinoki 2009). However, 17 $\beta$ estradiol suppresses enhancement of hyperactivation by progesterone (Fujinoki 2010). Melatonin also enhances hyperactivation (Fujinoki 2008). Those hormones are contained in follicular fluid and are found in reproductive fluids. Therefore, it seems that spermatozoa have several regulatory systems to regulate the timing of fertilization using hormones released from oocytes, COC, or follicular fluid. 

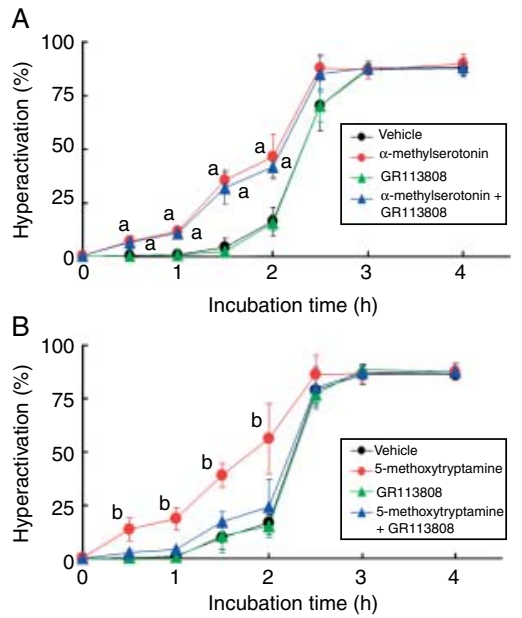

Figure 9 Effects of GR113808 on $\alpha$-methylserotonin-enhanced and 5-methoxytryptamine-enhanced hyperactivation. After spermatozoa were exposed to GR113808 for $5 \mathrm{~min}$, they were exposed to $\alpha$-methylserotonin or 5-methoxytryptamine. The percentages of hyperactivated spermatozoa (A and B) are shown when $100 \mathrm{fmol} / \mathrm{I}$ $\alpha$-methylserotonin, $10 \mathrm{pmol} / \mathrm{l} 5$-methoxytryptamine, and $1 \mu \mathrm{mol} / \mathrm{l}$ GR113808 were added to mTALP medium. Data are given as mean \pm s.D. In (A), 'vehicle', ' $\boldsymbol{\alpha}$-methylserotonin', 'GR113808', and ' $\alpha$-methylserotonin + GR113808' indicate mTALP+0.1\% DMSO, $\mathrm{mTALP}+100 \mathrm{fmol} / \mathrm{l} \alpha$-methylserotonin, $+0.1 \%$ DMSO, mTALP $+1 \mu \mathrm{mol} / \mathrm{l} \mathrm{GR} 113808+0.1 \% \mathrm{DMSO}$, and $\mathrm{mTALP}+100 \mathrm{fmol} / \mathrm{l}$ $\alpha$-methylserotonin, $+1 \mu \mathrm{mol} / \mathrm{l} \mathrm{GR} 113808+0.1 \%$ DMSO. In (B), 'vehicle', '5-methoxytryptamine', 'GR113808', and '5-methoxytryptamine + GR113808' indicate mTALP + 0.1\% DMSO + 0.1\% EtOH, $\mathrm{mTALP}+10 \mathrm{pmol} / \mathrm{l}$ 5-methoxytryptamine $+0.1 \% \mathrm{DMSO}+0.1 \%$ $\mathrm{EtOH}, \mathrm{mTALP}+1 \mu \mathrm{mol} / \mathrm{l} \mathrm{GR} 113808+0.1 \% \mathrm{DMSO}+0.1 \% \mathrm{EtOH}$, and mTALP+ $10 \mathrm{pmol} / \mathrm{l}$ 5-methoxytryptamine $+1 \mu \mathrm{mol} / \mathrm{l}$ GR113808

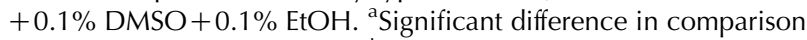
with 'vehicle' or 'GR113808'. ' Significant difference in comparison with 'vehicle' or 'GR113808' or '5-methoxytryptamine+GR113808'.

\section{Materials and Methods}

\section{Chemicals}

Serotonin, 2-(1-piperazinyl)quinoline maleate salt (quipazine maleate salt), 5-methoxytryptamine, cyproheptadine hydrochloride sesquihydrate, ( \pm )-3-(2-aminopropyl)indol-5-ol maleate salt ( $\alpha$-methylserotonin maleate salt or $\alpha$-methyl-5hydroxytryptamine maleate salt), and 1-[2-[(methylsulfonyl)amino] ethyl]-4-piperidinyl]methyl 1-methyl-1 $\mathrm{H}$-indole-3carboxylate (GR113808) were purchased from Sigma Chemical Company. BSA fraction $V$ was purchased from Merck KGaA. Other reagent grade chemicals were purchased from Wako Pure Chemical Industries (Osaka, Japan).

\section{Preparation of hyperactivated spermatozoa}

Spermatozoa were obtained from the caudal epididymis of sexually mature (10-20 week old) male golden hamsters (Mesocricetus auratus), which were housed in accordance with the Dokkyo Medical University and Laboratory Animal Research Center in Dokkyo Medical University guidelines for the care and use of laboratory animals.
Hyperactivated spermatozoa were prepared according to the method described by Fujinoki et al. (2006) using a modified mTALP medium containing $101.02 \mathrm{mmol} / \mathrm{l} \mathrm{NaCl}, 2.68 \mathrm{mmol} / \mathrm{l}$ $\mathrm{KCl}, 2 \mathrm{mmol} / \mathrm{l} \mathrm{CaCl}, 1.5 \mathrm{mmol} / \mathrm{l} \mathrm{MgCl} 2 \cdot 6 \mathrm{H}_{2} \mathrm{O}, 0.36 \mathrm{mmol} / \mathrm{l}$ $\mathrm{NaH}_{2} \mathrm{PO}_{4} \cdot 2 \mathrm{H}_{2} \mathrm{O}, 35.70 \mathrm{mmol} / \mathrm{l} \mathrm{NaHCO}, 4.5 \mathrm{mmol} / \mathrm{l}$ D-glucose, $0.09 \mathrm{mmol} / \mathrm{l}$ sodium pyruvate, $9 \mathrm{mmol} / \mathrm{l}$ sodium lactate, $0.5 \mathrm{mmol} / \mathrm{l}$ hypotaurine, $0.05 \mathrm{mmol} / \mathrm{l}$ (-)epinephrine, $0.2 \mathrm{mmol} / \mathrm{l}$ sodium taurocholic acid, $5.26 \mu \mathrm{mol} / \mathrm{l}$ sodium metabisulfite, $0.05 \%(\mathrm{w} / \mathrm{v})$ streptomycin sulfate, $0.05 \%(\mathrm{w} / \mathrm{v})$ potassium penicillin $\mathrm{G}$, and $15 \mathrm{mg} / \mathrm{ml} \mathrm{BSA}\left(\mathrm{pH} 7.4\right.$ at $37^{\circ} \mathrm{C}$ under $5 \%(\mathrm{v} / \mathrm{v}) \mathrm{CO}_{2}$ in air). An aliquot of caudal epididymal spermatozoa was placed on a culture plate $(35 \mathrm{~mm}$ dish) and several milliliters of the medium were carefully added before incubation for $5 \mathrm{~min}$ to allow spermatozoa to swim up. The supernatant containing motile spermatozoa was collected, placed on the culture plate, and incubated for $4 \mathrm{~h}$ at $37^{\circ} \mathrm{C}$ under $5 \% \mathrm{CO}_{2}$ in air to accomplish hyperactivation. Serotonin and agonists were added to the medium after placing motile spermatozoa on the culture plate. For examination of the effects
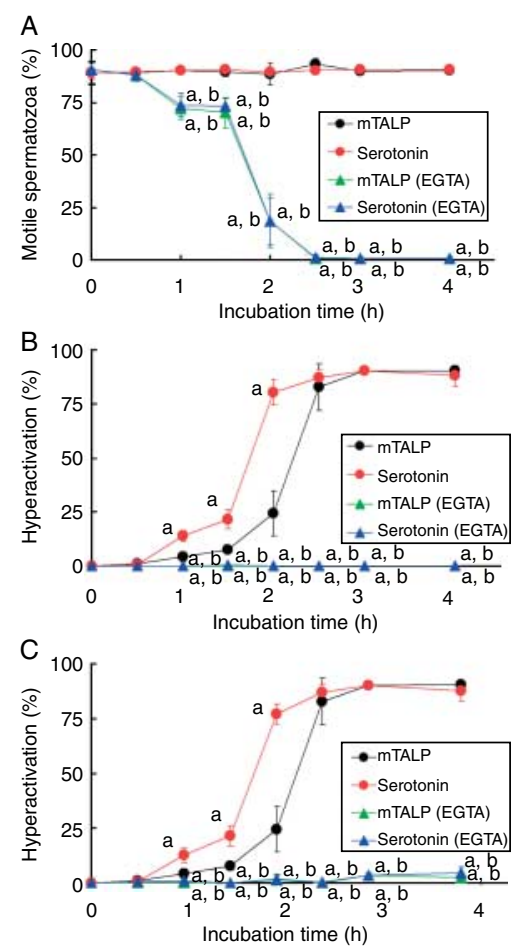

Figure 10 Effects of $\mathrm{Ca}^{2+}$ and albumin on serotonin-enhanced hyperactivation. The percentages of motile spermatozoa (A) and hyperactivated spermatozoa $(\mathrm{B})$ are shown when $\mathrm{Ca}^{2+}$ was removed from the mTALP medium using $1 \mathrm{mmol} / \mathrm{I}$ EGTA. Data are given as mean \pm s.D. 'mTALP', 'serotonin', 'mTALP (EGTA)', and 'serotonin (EGTA)' indicate mTALP only, $\mathrm{mTALP}+100 \mathrm{pmol} / \mathrm{l}$ serotonin, $\mathrm{mTALP}$ without $\mathrm{Ca}^{2+}+1 \mathrm{mmol} / \mathrm{EGTA}$, and $\mathrm{mTALP}$ without $\mathrm{Ca}^{2+}$ $+100 \mathrm{pmol} / \mathrm{l}$ serotonin $+1 \mathrm{mmol} / \mathrm{l}$ EGTA. The percentages of hyperactivated spermatozoa (C) are shown when albumin was removed from the mTALP medium. Data are given as mean \pm s.D. 'mTALP', 'serotonin', 'mTALP (-BSA)', and 'serotonin (-BSA)' indicate mTALP, $\mathrm{mTALP}+100 \mathrm{pmol} / \mathrm{l}$ serotonin, mTALP without BSA, and mTALP without $\mathrm{BSA}+100 \mathrm{pmol} / \mathrm{l}$ serotonin. ${ }^{\mathrm{a}}$ Significant difference in comparison with 'mTALP'; b significant difference in comparison with 'serotonin'. 
of serotonin antagonists, spermatozoa were exposed to serotonin and agonists after exposure to antagonists for 5 min. Cyproheptadine, 5-methoxytryptamine, and GR113808 were dissolved in methanol $(\mathrm{MeOH})$, ethanol $(\mathrm{EtOH})$, and DMSO. In all experiments, the maximal concentration of vehicle was $0.2 \%$.

\section{Measurement of spermatozoa motility and hyperactivation}

Motility and hyperactivation measurements were performed according to the method described by Fujinoki et al. (2006) with some modifications. Spermatozoa suspended in the mTALP medium were diluted tenfold and placed on a culture plate. Motility and hyperactivation were recorded on $\mathrm{VHS}$ via a CCD camera (Progressive 3CCD, Sony Corp., Tokyo, Japan) attached to a microscope (IX70, Olympus Corp., Tokyo, Japan) with phase-contrast illumination and a small $\mathrm{CO}_{2}$ incubator (MI-IBC, Olympus). Each observation was performed at $37^{\circ} \mathrm{C}$, recorded for $2 \mathrm{~min}$, and analyzed by manually counting the number of total spermatozoa, motile spermatozoa, and hyperactivated spermatozoa in ten different fields. Motile spermatozoa that exhibited asymmetric and whiplash flagellar movement and a circular and/or octagonal swimming locus were defined as hyperactivated spermatozoa (Fujinoki et al. 2001a). Motile spermatozoa (\%) and hyperactivated spermatozoa (\%) were, respectively, defined as the number of motile spermatozoa/number of total spermatozoa $\times 100$, and the number of hyperactivated spermatozoa/number of total spermatozoa $\times 100$. Experiments were performed four times using four hamsters. Statistical analyses were performed using the post hoc ANOVA test. $P<0.05$ was considered significant.

\section{Declaration of interest}

The author declares that there is no conflict of interest that could be perceived as prejudicing the impartiality of the research reported.

\section{Funding}

This research was partially supported by a Grant-in-Aid for Young Scientists (B) from the Ministry of Education, Culture, Sports, Science and Technology of Japan (no. 18791135).

\section{References}

Baldi E, Luconi M, Muratori M, Marchiani S, Tamburrino L \& Forti G 2009 Nongenomic activation of spermatozoa by steroid hormones: facts and fictions. Molecular and Cellular Endocrinology 308 39-46. (doi:10. 1016/j.mce.2009.02.006)

Bódis J, Bognàr Z, Hartmann G, Török A \& Csaba IF 1992 Measurement of noradrenaline, dopamine and serotonin contents in follicular fluid of human graafian follicles after superovulation treatment. Gynecologic and Obstetric Investigation 33 165-167. (doi:10.1159/000294873)

Bódis J, Török A, Tinneberg HR, Hanf V, Papenfuss F \& Schwarz H 1993 Serotonin induces progesterone release from human granulose cells in a superfused granulose cell system. Archives of Gynecology and Obstetrics 253 59-64. (doi:10.1007/BF02768730)
Breitbart H 2002 Intracellular calcium regulation in sperm capacitation and acrosomal reaction. Molecular and Cellular Endocrinology 187 139-144. (doi:10.1016/S0303-7207(01)00704-3)

Casao A, Mendoza N, Pérez-Pé R, Grasa P, Abecia JA, Forcada F, CebriánPérez JA \& Muino-Blanco T 2009 Melatonin prevents capacitation and apoptotic-like changes of ram spermatozoa and increases fertility rate. Journal of Pineal Research 48 39-46. (doi:10.1111/j.1600-079X.2009. 00722.x)

Dubé F \& Amireault P 2007 Local serotonergic signaling in mammalian follicles, oocytes and early embryos. Life Sciences 81 1627-1637. (doi:10.1016/j.Ifs.2007.09.034)

Fujinoki M 2008 Melatonin-enhanced hyperactivation of hamster sperm. Reproduction 136 533-541. (doi:10.1530/REP-08-0202)

Fujinoki M 2009 Non-genomic regulation of mammalian sperm hyperactivation. Reproductive Medicine and Biology 8 47-52. (doi:10.1007/ s12522-009-0012-2)

Fujinoki M 2010 Suppression of progesterone enhanced hyperactivation in hamster spermatozoa by estrogen. Reproduction 140 453-464. (doi:10. 1530/REP-10-0168)

Fujinoki M, Ohtake H \& Okuno M 2001a Serine phosphorylation of flagellar proteins associated with the motility activation of hamster spermatozoa. Biomedical Research 22 45-58.

Fujinoki M, Ohtake H \& Okuno M 2001b Tyrosine phosphorylation and dephosphorylation associated with motility of hamster spermatozoa. Biomedical Research 22 147-155.

Fujinoki M, Kawamura T, Toda T, Ohtake H, Ishimoda-Takagi T, Shimizu N, Yamaoka S \& Okuno M 2003 Identification of 36-kDa flagellar phosphoproteins associated with hamster sperm motility. Journal of Biochemistry 133 361-369. (doi:10.1093/jb/mvg048)

Fujinoki M, Kawamura T, Toda T, Ohtake H, Ishimoda-Takagi T, Shimizu N, Yamaoka S \& Okuno M 2004a Identification of 36 kDa phosphoprotein in fibrous sheath of hamster spermatozoa. Comparative Biochemistry and Physiology 137 509-520. (doi:10.1016/j.cbpc.2004.02.006)

Fujinoki M, Ishimoda-Takagi T \& Ohtake H 2004b Serine/threonine phosphorylation associated with hamster sperm hyperactivation. Reproductive Medicine and Biology 3 223-230. (doi:10.1111/j.14470578.2004.00069.x)

Fujinoki M, Suzuki T, Takayama T, Shibahara H \& Ohtake H 2006 Profiling of proteins phosphorylated or dephosphorylated during hyperactivation via activation on hamster spermatozoa. Reproductive Medicine and Biology 5 123-135. (doi:10.1111/j.1447-0578.2006.00133.x)

Ganong WF 2005 Synaptic and junctional transmission. In Review of Medical Physiology, 22 edn, pp 85-127. Ed. WF Ganong. New York: The McGraw-Hill Companies.

Ho HC \& Suarez SS 2001 An inositol 1,4,5-trisphoshate receptor-gated intracellular $\mathrm{Ca}^{2+}$ store is involved in regulating sperm hyperactivated motility. Biology of Reproduction 65 1606-1616. (doi:10.1095/biolreprod65.5.1606)

Ho HC, Granish KA \& Suarez SS 2002 Hyperactivated motility of bull sperm is triggered at the axoneme by $\mathrm{Ca}^{2+}$ and not CAMP. Developmental Biology 250 208-217. (doi:10.1006/dbio.2002.0797)

Juorio AV, Chedrese PJ \& Li XM 1989 The influence of ovarian hormones on the rat oviductal and uterine concentration of noradrenaline and 5-hydroxytryptamine. Neurochemical Research 14 821-827. (doi:10. 1007/BF00964810)

Langlais J \& Roberts KD 1985 A molecular membrane model of sperm capacitation and the acrosome reaction of mammalian spermatozoa. Gamete Research 12 183-224. (doi:10.1002/mrd.1120120209)

Luconi M, Francavilla F, Porazzi I, Macerola B, Forti G \& Baldi E 2004 Human spermatozoa as a model for studying membrane receptors mediating rapid nongenomic effects of progesterone and estrogens. Steroids 69 553-559. (doi:10.1016/j.steroids.2004.05.013)

Marín-Briggiler CI, Jha KN, Chertihin O, Buffone MG, Herr JC, VazquezLevin MH \& Visconti PE 2005 Evidence of the presence of calcium/calmodulin-dependent protein kinase IV in human sperm and its involvement in motility regulation. Journal of Cell Science $\mathbf{1 1 8}$ 2013-2022. (doi:10.1242/jcs.02326)

Meizel S \& Turner KO 1983 Serotonin or its agonist 5-methoxytryptamine can stimulate hamster sperm acrosome reactions in a more direct manner than catecholamines. Journal of Experimental Zoology 226 171-174. (doi:10.1002/jez.1402260120) 
Noda M, Higashida H, Aoki S \& Wada K 2004 Multiple signal transduction pathways mediated by 5-HT receptors. Molecular Neurobiology 29 31-39. (doi:10.1385/MN:29:1:31)

Noguchi T, Fujinoki M, Kitazawa M \& Inaba N 2008 Regulation of hyperactivation of hamster spermatozoa by progesterone. Reproductive Medicine and Biology 7 63-74. (doi:10.1111/j.1447-0578.2008. 00202.x)

Okamura N, Tajima Y, Soejima A, Masuda H \& Sugita Y 1985 Sodium bicarbonate in seminal plasma stimulates the motility of mammalian spermatozoa through direct activation of adenylate cyclase. Journal of Biological Chemistry $2609699-9705$.

Osman RA, Andria ML, Jones AD \& Meizel S 1989 Steroid induced exocytosis: the human sperm acrosome reaction. Biochemical and Biophysical Research Communications 160 828-833. (doi:10.1016/ 0006-291X(89)92508-4)

du Plessis SS, Hagenaar K \& Lampiao F 2010 The in vitro effects of melatonin on human sperm function and its scavenging activities on $\mathrm{NO}$ and ROS. Andrologia 42 112-116. (doi:10.1111/j.1439-0272.2009. 00964.x)

Suarez SS \& Ho HC 2003 Hyperactivated motility in sperm. Reproduction in Domestic Animals 38 119-124. (doi:10.1046/j.1439-0531.2003. 00397.x)

Sueldo CE, Alexander NJ, Oehninger S, Burkman LJ, Subias E, Acosta AA \& Mahony M 1993 Effect of progesterone on human zona pellucida sperm binding and oocyte penetrating capacity. Fertility and Sterility $\mathbf{6 0}$ 137-140.

Visconti PE \& Kopf GS 1998 Regulation of protein phosphorylation during sperm capacitation. Biology of Reproduction 59 1-6. (doi:10.1095/ biolreprod59.1.1)
Visconti PE, Moore GD, Bailey JL, Leclerc P, Connors SA, Pan D, Old-Clarke P \& Kopf GS 1995 Capacitation of mouse spermatozoa II. Protein tyrosine phosphorylation and capacitation are regulated by a cAMP-dependent pathway. Development 121 1139-1150.

Visconti PE, Galantino-Homer H, Moore GD, Bailey JL, Ning X, Fornes M \& Kopf GS 1998 The molecular basis of sperm capacitation. Journal of Andrology 19 242-248.

Visconti PE, Stewart-Savage J, Blasco A, Battaglia L, Miranda P, Kopf GS \& Tezón JG 1999 Roles of bicarbonate, cAMP, and protein tyrosine phosphorylation on capacitation and the spontaneous acrosome reaction of hamster sperm. Biology of Reproduction 61 76-84. (doi:10.1095/ biolreprod61.1.76)

Yanagimachi R 1994 Mammalian fertilization. In The Physiology of Reproduction, vol 2, 2nd edn, pp 189-317. Eds E Knobil \& JD Neill. New York: Raven Press.

Yang J, Serres C, Philibert D, Robel P, Baulieu EE \& Jouannet P 1994 Progesterone and RU486: opposing effects on human sperm. PNAS 91 529-533. (doi:10.1073/pnas.91.2.529)

Yudine AI, Gottlieb W \& Meizel S 1988 Ultrastructural studies of the early events of the human sperm acrosome reaction as initiated by human follicular fluid. Gamete Research 20 11-24. (doi:10.1002/mrd. 1120200103)

Received 10 March 2011

First decision 12 April 2011

Accepted 9 May 2011 